OCCASIONAL PAPER

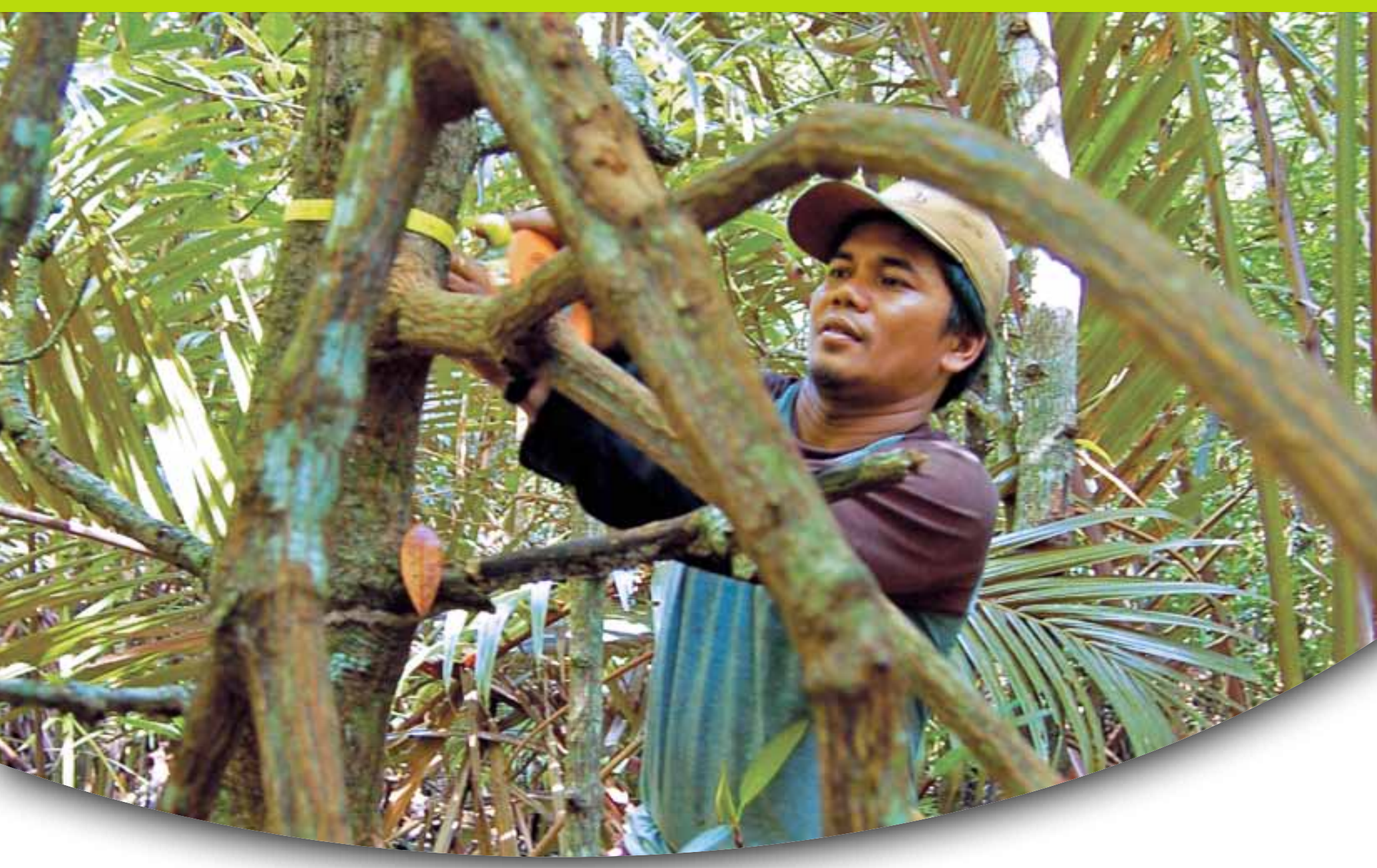

\title{
Review of existing methods for carbon accounting
}

David Neil Bird

Naomi Pena

Hannes Schwaiger

Giuliana Zanchi
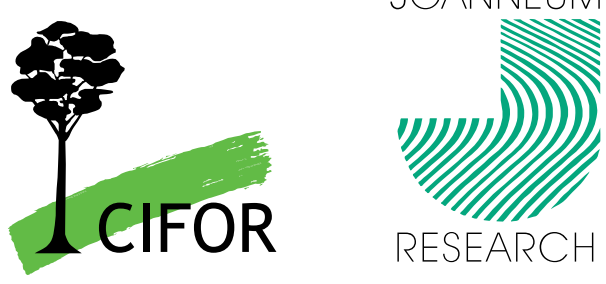



\section{Review of existing methods for carbon accounting}

David Neil Bird

Naomi Pena

Hannes Schwaiger

Giuliana Zanchi 
This report has been produced with the financial assistance of the European Union, under a project titled, 'Bioenergy, sustainability and trade-offs: Can we avoid deforestation while promoting bioenergy?' The objective of the project is to contribute to sustainable bioenergy development that benefits local people in developing countries, minimizes negative impacts on local environments and rural livelihoods, and contributes to global climate change mitigation. The project will achieve this by producing and communicating policy relevant analyses that can inform government, corporate and civil society decision-making related to bioenergy development and its effects on forests and livelihoods. The project is managed by CIFOR and implemented in collaboration with the Council on Scientific and Industrial Research (South Africa), Joanneum Research (Austria), the Universidad Autónoma de México and the Stockholm Environment Institute. The views expressed herein can in no way be taken to reflect the official opinion of the European Union.

Occasional Paper 54

(c) 2010 Center for International Forestry Research.

All rights reserved.

ISBN 978-602-8693-27-1

Bird, D.N., Pena, N., Schwaiger, H. and Zanchi, G. 2010 Review of existing methods for carbon accounting. Occasional paper 54. CIFOR, Bogor, Indonesia.

Cover photo by Daniel Murdiyarso

\author{
CIFOR \\ Jl. CIFOR, Situ Gede \\ Bogor Barat 16115 \\ Indonesia \\ $\mathrm{T}+62$ (251) 8622-622 \\ $F+62(251) 8622-100$ \\ E cifor@cgiar.org
}

\title{
www.cifor.cgiar.org
}




\section{Contents}

List of abbreviations and definitions vi

Executive summary viii

1 Introduction $\quad 1$

2 Existing methods for carbon accounting 2

2.1 IPCC methodology 2

2.2 EU Renewable Energy Directive 6

2.3 Clean Development Mechanism methodologies 9

$\begin{array}{lll}2.4 & \text { Voluntary Carbon Standard methodologies } & 10\end{array}$

3 Examples 11

3.1 Reforestation: Grassland to forest: South Africa - short rotation forestry 11

3.2 Forest degradation: Unmanaged forests to plantations: Malaysia - palm plantations on native forest 14

3.3 Forest management: Use of harvest residuals: Austria - collection of thinning and harvest residuals

3.4 Deforestation: Forests to cropland: Mexico - a mixed pine/oak forest converted to cornfield

4.1 Ideas for improving carbon accounting methods 27

$\begin{array}{lr}\text { Endnotes } & 29\end{array}$

$\begin{array}{ll}\text { References } & 31\end{array}$

Annex - Parameters

1 Reforestation: Grassland to forest: South Africa - short rotation forestry 34

2 Forest degradation: Unmanaged forests to plantations: Malaysia - palm plantations on native forest $\quad 35$

3 Forest management: Use of harvest residuals: Austria - collection of thinning and harvest residuals 36

4 Deforestation: Forests to cropland: Mexico - a mixed pine/oak forest converted to cornfield 


\section{List of figures}

1 Contribution of dead organic matter (DOM) and soil organic carbon (SOC) to total carbon stock change

2 Cumulative carbon stock changes in the first 20 years as a percentage of the total carbon stock changes during the first rotation

4 Reforestation example: A comparison of the total carbon stock changes by year under the 4 accounting methods

5 Reforestation example: Stand and 'averaged forest' biomass

6 Forest degradation example: Comparison of the total carbon stock changes by year under the 4 accounting methods

7 Forest degradation example: Stand and 'averaged forest' biomass

8 Use of harvest residuals example: Comparison of the total carbon stock changes by year under the 4 accounting methods

9 Use of harvest residuals example: Stand and 'averaged forest' biomass

10 Deforestation example: Comparison of the total carbon stock changes by year under the 4 accounting methods

11 Deforestation example: Stand biomass

12 Cumulative carbon stock changes in dead organic matter (DOM) and soil organic carbon (SOC) in the first rotation as a percentage of the total carbon stock changes

13 Cumulative carbon stock changes in the first 20 years as a percentage of the total carbon stock changes during the first rotation 


\section{List of tables}

1 Comparison of the cumulative carbon stock changes in the first rotation for the 4 examples under the 4 accounting methods

2 Reforestation example: Comparison of the cumulative carbon stock changes in the first rotation under the 4 accounting methods

3 Forest degradation example: Comparison of the cumulative carbon stock changes in the first rotation under the 4 accounting methods

4 Use of harvest residuals example: Comparison of the cumulative carbon stock changes in the first rotation years under the 4 accounting methods

5 Deforestation example: Comparison of the cumulative carbon stock changes after 20 years under the 4 accounting methods

6 Default values for aboveground biomass

7 Cumulative carbon stock changes over the first rotation as a percentage of the Tier 3 estimate 25

8 Cumulative carbon stock changes in DOM and SOC in the first 20 years as a percentage of the Tier 3 estimate 


\title{
List of abbreviations and definitions
}

\author{
$\mathrm{AB} \quad$ Aboveground living biomass \\ AFOLU Agriculture, forestry and other land use \\ $\mathrm{A} / \mathrm{R} \quad$ Afforestation and reforestation \\ $\mathrm{BB} \quad$ Belowground living biomass (roots) \\ CDM Clean Development Mechanism \\ DOM Dead organic matter \\ FAO Food and Agriculture Organization of the United Nations \\ HWP Harvested wood products \\ IEA International Energy Agency \\ iLUC Indirect land use change
}

Industrial The commodities included are sawlogs or veneer logs, pulpwood, other industrial roundwood roundwood and, in the case of trade, chips and particles and wood residues. Industrial roundwood includes:

- Pulpwood (round and split): Wood in the rough other than logs, used for pulp, particle board or fibreboard. Pulpwood may be barked or unbarked and may be in the form of roundwood or splitwood. In production, it may include the equivalent of wood chips made directly from roundwood.

- Sawlogs, veneer logs and logs for sleepers: Logs whether or not roughly squared, to be sawn (or chipped) lengthwise for the manufacture of sawnwood or railway sleepers (ties). Shingle bolts and stave bolts are included. Logs for production of veneer, mainly by peeling or slicing. Match billets are included, as are special growths (burls, roots, etc.) used for veneers.

- Other industrial roundwood: Roundwood used for tanning, distillation, match blocks, gazogenes, poles, piling, posts, pitprops, etc.

IPCC Intergovernmental Panel on Climate Change

ICERs Long-term temporary removals

LULUCF Land use, land use change and forestry

REDD+ Reducing emissions from deforestation and forest degradation

R:S Root to shoot ratio

SOC Soil organic carbon

SWD Solid waste disposal

tCERs Short-term temporary removals

UNFCCC United Nations Framework Convention on Climate Change

VCS Voluntary Carbon Standard

Wood fuel Wood in the rough (from trunks and branches of trees) to be used as fuel for such purposes as cooking, heating or power production. Includes wood from coniferous and non-coniferous species. 


\section{Executive summary}

$\mathrm{F}$ Torests are sources of biomass that can be used to create forest-based bioenergy, whether directly by establishing energy plantations on non-forestland, by using existing forest resources or by using residues from harvesting for nonbioenergy purposes. If created in a sustainable manner, this bioenergy can have significant positive greenhouse gas benefits. However, past experience provides strong reason to believe that significant bioenergy development will come at the expense of natural forests, either through direct conversion of forests to non-forestland or through indirect competition between land uses. Bioenergy development may increase the demand for agricultural land, which may be sourced from tropical forests. In this case, the net carbon balance would be highly negative.

This paper first reviews existing methods for carbon accounting for forest-based bioenergy development. The review examines methodologies from:

1. the IPCC Good Practice Guidance for Land Use, Land-Use Change and Forestry (GPGLULUCF) and the 2006 IPCC Guidelines for National Greenhouse Gas Inventories (2006 IPCC Guidelines); and

2. Directive 2009/28/EC of the European Parliament and of the Council (EU Renewable Energy Directive).

The 2006 IPCC Guidelines adopt a tiered approach for accounting in which the lowest tier (Tier 1) uses default parameters for the estimation and simplified methodologies that are land use change specific. The middle tier (Tier 2) uses in general the same methodologies as Tier 1 but includes national or regional data to make the estimate. The highest tier (Tier 3) employs complex carbon flow models that are parameterised with regionally specific information (full carbon accounting). The EU Renewable Energy Directive adopts its own methodology (in particular, linearisation of the carbon stock changes over 20 years) based on the approaches in the 2006 IPCC Guidelines.

The paper then uses examples to illustrate the benefits and shortcomings of the reviewed methodologies. The examples were chosen to highlight specific cases of land use change that may occur in bioenergy development. The 4 cases are:

1. reforestation: conversion of grasslands to short rotation forests;

2. forest degradation: conversion of unmanaged forests to plantations;

3. forest management: use of harvest residuals; and

4. deforestation: conversion of natural forests to croplands.

These examples highlight the necessity of:

- using Tier 2 or Tier 3 methods to calculate the carbon stock changes from land use changes that involve forestry;

- including dead wood and litter pools in the estimation of emissions, particularly when estimating emissions from deforestation and when the land use change involves only these pools; and

- using a linear approximation over the first rotation and not a specific predetermined length of time, if a simplified forest carbon stock dynamics is to be used.

The first of these has already been identified by numerous authors, particularly in the discussion of methodologies for estimating emissions from 
deforestation. The reason for its importance is the considerable uncertainty surrounding the default values for aboveground biomass used in the Tier 1 methodology. By contrast, few authors have examined the impact of including or excluding dead wood and litter. Furthermore, to our knowledge, no one has challenged the 20 year linearisation assumption adopted in the $E U$ Renewable Energy Directive.
The results of the analysis are summarised in Table 1. Most of the differences between the results derived from using the 4 accounting methods are attributable to variations in assumptions of the amount of aboveground biomass (Tier 1 versus Tiers 2 and 3). Figure 1 shows the relative contributions of dead organic matter (DOM) and soil organic carbon (SOC) to carbon stock change; Figure 2 illustrates the importance of calculating emissions over longer time periods.

Table 1. Comparison of the cumulative carbon stock changes in the first rotation for the 4 examples under the 4 accounting methods

\begin{tabular}{lrrccc}
\hline \multicolumn{1}{c}{ Activity } & \multicolumn{3}{c}{ IPCC } & & EU Renewable Energy Directive \\
\hline Reforestation & Tier 1 & Tier 2 & Tier 3 & $-81 \%$ \\
Degradation & $10 \%$ & $-17 \%$ & $0 \%$ & $70 \%$ \\
Dead organic matter management & $71 \%$ & $-2 \%$ & $0 \%$ & $-100 \%$ \\
Deforestation & $-100 \%$ & \multicolumn{2}{c}{$0 \%$} & & $-46 \%$ \\
\hline
\end{tabular}

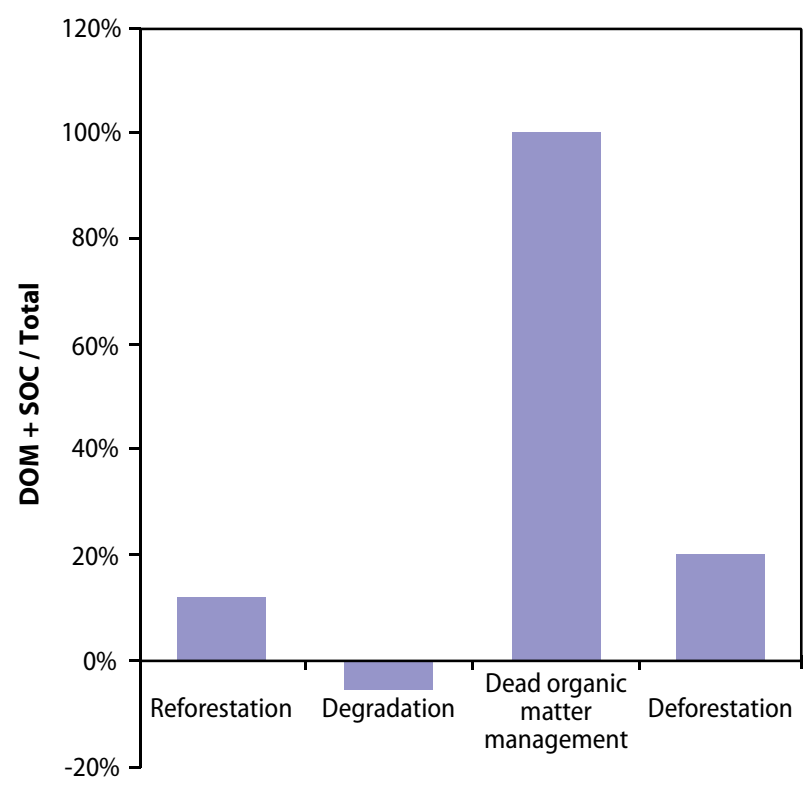

Figure 1. Contribution of dead organic matter (DOM) and soil organic carbon (SOC) to total carbon stock change

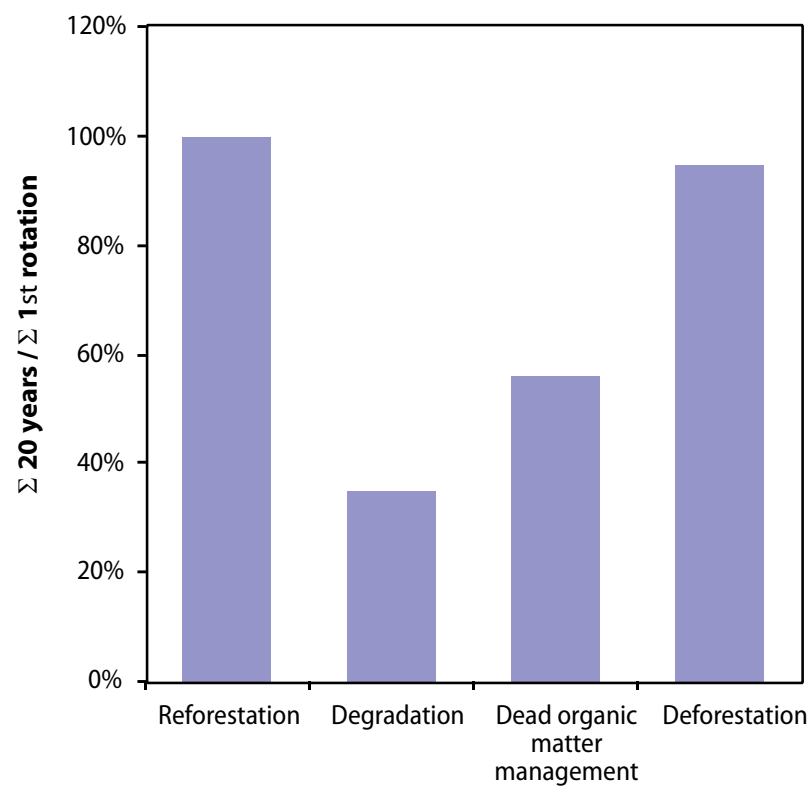

Figure 2. Cumulative carbon stock changes in the first 20 years as a percentage of the total carbon stock changes during the first rotation 


\section{Introduction}

F orests are sources of biomass that can be used to create forest-based bioenergy, by establishing energy plantations on nonforestland, by using existing forest resources or by using residues from harvesting for nonbioenergy purposes. If created in a sustainable manner, this bioenergy can have significant positive greenhouse gas benefits. However, past experience provides strong reason to believe that significant bioenergy development will come at the expense of natural forests, either directly, through conversion of forests to non-forestland, or indirectly, through competition between land uses. Bioenergy development may increase the demand for agricultural land; if such land is sourced from tropical forests, the net carbon balance would be highly negative.

This paper reviews existing methods for carbon accounting (with respect to full carbon accounting) for forest-based bioenergy development. This review was undertaken as part of a larger project designed to assess the potential of forest-based bioenergy for climate change mitigation. The review examines methodologies from:

1. the IPCC Good Practice Guidance for Land Use, Land-Use Change and Forestry (GPGLULUCF; IPCC 2003) and the IPCC Guidelines for National Greenhouse Gas Inventories (2006 IPCC Guidelines; IPCC 2006); and
2. Directive $2009 / 28 / \mathrm{EC}$ of the European Parliament and of the Council (EU Renewable Energy Directive; European Union 2009).

The paper uses examples to illustrate the benefits and shortcomings of the reviewed methodologies. The 4 examples, chosen to highlight specific cases, are:

1. reforestation: conversion of grasslands to short rotation forests;

2. forest degradation: conversion of unmanaged forests to plantations;

3. forest management: use of harvest residuals; and

4. deforestation: conversion of natural forests to croplands.

In all cases, the biomass after conversion is assumed to be used for bioenergy production. The analysis focuses only on the differences in accounting of greenhouse gases caused by changes in the carbon stock in the biomass. The analysis uses the CO2FIX ${ }^{1}$ (Omar et al. 2003) and GORCAM ${ }^{2}$ (Marland and Schlamadinger 1995; Schlamadinger and Marland 1996) standbased carbon models as a basis for the analysis, using country-specific yield information, tree descriptions and climatic data as inputs. 


\section{Existing methods for carbon accounting}

\subsection{IPCC methodology}

The IPCC methodology is designed to calculate the emissions and removals from land use and land use change for a national inventory. As it does not aim to estimate the benefits of a project or an activity, the IPCC methodology does not discuss additionality, baselines or leakage. However, these concepts are important in assessing the climate change mitigation potential of project activities, including sustainable forest-based bioenergy.

\subsubsection{Treatment of bioenergy}

A very important aspect of the IPCC methodology is its treatment of emissions from the use of biomass for bioenergy. In particular, $\mathrm{CO}_{2}$ emissions from the combustion of biomass for energy are not accounted for in the energy sector (i.e. zero emissions), but are included as a change of stock in the agriculture, forestry and other land use (AFOLU) sector.

Bioenergy was allocated zero $\mathrm{CO}_{2}$ emissions in the energy sector because:

1. 'the net release of carbon should be evident in the calculation of $\mathrm{CO}_{2}$ emissions described in the Land Use Change and Forestry chapter' (IPCC 1996);

2. 'of the sustainable nature of biofuels' (IPCC 1996);

3. 'the accounting system should be as simple as possible, but not simpler' (Apps et al. 1997);
4. 'net emissions or removals of $\mathrm{CO}_{2}$ are estimated in the AFOLU sector and take account of these emissions' (IPCC 2006);

5. 'biomass data are generally more uncertain than other data in national energy statistics' (IPCC 2006);

6. 'a large fraction of the biomass, used for energy, may be part of the informal economy, and the trade is not registered in the national energy statistics and balances' (IPCC 2006); and

7. 'it avoids any double counting' (IPCC 2006).

It is clear from the IPCC guidelines (IPCC 1996, 2006) that bioenergy was considered to have zero $\mathrm{CO}_{2}$ emissions in the energy sector only, but not zero emissions overall.

This allotment of emissions is appropriate if all countries are reporting. However, as Searchinger et al. (2008) and Pingoud et al. (2010) point out, the Kyoto Protocol has some 'loop-holes'. The principle of comprehensiveness over space is violated is violated in the Kyoto Protocol because:

- some countries are not participating in the Kyoto Protocol (specifically developing countries); and

- in countries that are participating, some parts of the AFOLU sector are not included because only reporting carbon stock changes from afforestation, deforestation and reforestation is mandatory under the Kyoto Protocol. Hence reductions in carbon stock in a forest that remain forests may not be included. 
As not all emissions from the AFOLU sector are included, the assumption of zero $\mathrm{CO}_{2}$ emissions from bioenergy in the energy sector is not valid, and the emission benefits from bioenergy are overestimated.

Given this, in the present report we focus on accounting in the AFOLU sector and do not discuss emissions in the energy sector.

\subsubsection{Framework}

The IPCC methodology for carbon accounting uses a generic framework combined with a 3-tiered approach to data quality and complexity.

The generic framework estimates the carbon stock changes in 5 pools, on an annual basis across the following 6 land use categories:

1. forestland;

2. cropland;

3. grassland;

4. wetlands;

5. settlements; and

6. other land.

The 5 pools are:

1. aboveground biomass; ${ }^{3}$

2. belowground biomass; ${ }^{4}$

3. dead wood; ${ }^{5}$

4. litter; $^{6}$ and

5. soil. $^{7}$

In addition, a 6th pool, harvested wood products $(\mathrm{HWP})^{8}$, should be reported at the national level.

Therefore, carbon stock changes from land use are generally calculated on an annual basis using the following formula:

$$
\begin{aligned}
\Delta C_{A F O L U}= & \Delta C_{F L}+\Delta C_{C L}+\Delta C_{G L}+\Delta C_{W L}+\Delta C_{S}+ \\
& \Delta C_{O L}+\Delta C_{H W P}
\end{aligned}
$$

where:

$\triangle C_{A F O L U}$ carbon stock change from AFOLU, $\mathrm{tC} / \mathrm{yr}$

$\Delta C_{F L} \quad$ carbon stock change on forestland, $\mathrm{tC} / \mathrm{yr}$

$\Delta C_{C L} \quad$ carbon stock change on cropland, $\mathrm{tC} / \mathrm{yr}$

$\Delta C_{G L} \quad$ carbon stock change on grassland, $\mathrm{tC} / \mathrm{yr}$
$\Delta C_{W L} \quad$ carbon stock change on wetlands, $\mathrm{tC} / \mathrm{yr}$

$\Delta C_{S} \quad$ carbon stock change on settlements, $\mathrm{tC} / \mathrm{yr}$

$\Delta C_{O L} \quad$ carbon stock change on other lands, $\mathrm{tC} / \mathrm{yr}$

$\Delta C_{H W P} \quad$ carbon stock change in harvested wood products, $\mathrm{tC} / \mathrm{yr}$

For each land use, the carbon stock changes in each pool are estimated and summed. Therefore:

$\Delta C_{L U i}=\Delta C_{A B}+\Delta C_{B B}+\Delta C_{D W}+\Delta C_{L I}+\Delta C_{S O}$

where:

$\Delta C_{L U i} \quad$ carbon stock change in land use, $i, \mathrm{tC} / \mathrm{yr}$

$\Delta C_{A B} \quad$ carbon stock change in aboveground living biomass, $\mathrm{tC} / \mathrm{yr}$

$\triangle C_{B B} \quad$ carbon stock change in belowground living biomass, $\mathrm{tC} / \mathrm{yr}$

$\Delta C_{D W} \quad$ carbon stock change in dead wood, $\mathrm{tC} / \mathrm{yr}$

$\Delta C_{L I} \quad$ carbon stock change in litter, $\mathrm{tC} / \mathrm{yr}$

$\Delta C_{S O} \quad$ carbon stock change in soils, $\mathrm{tC} / \mathrm{yr}$

\subsubsection{Key categories}

The IPCC inventory system uses the concept of 'key category' to identify sectors and items that have a significant influence on a country's total inventory of greenhouse gases. The significance can be in terms of the absolute level of, trend in or uncertainty in emissions and removals. Generally, if an item is considered a key category, then it is accounted for using a more detailed method or level of complexity (tier).

\subsubsection{Tier structure}

The tier structure relates to the availability of data and the quality of the estimate of the accounting. The higher the tier, the more comprehensive and complete is the carbon accounting but more detailed data are required.

Tier 1 is the simplest methodology to use. The 2006 IPCC Guidelines provide equations and default parameter values. Country-specific activity data are needed, but in Tier 1 missing or unavailable activity data can be replaced by estimates based on globally available sources of data. 
Tier 2 uses the same methodological approach as Tier 1 but applies country- or region-specific parameters and activity data that are more appropriate for the climatic conditions and land use and agricultural systems in the country.

Tier 3 applies models and inventory measurement systems specific to address national circumstances, repeated over time and driven by high-resolution activity data and disaggregated at subnational level. Models and measurement systems must undergo quality checks, audits and validations and be thoroughly documented. In this paper, Tier 3 is equivalent to full carbon accounting and is estimated using the models described in the introduction.

Depending on country circumstances and the tier chosen, stock changes may not be estimated for all pools. For example, Tier 1 methods include the following simplifying assumptions:

- changes in belowground biomass carbon stocks are assumed to be zero;

- dead wood and litter pools are often grouped together as DOM and

- DOM stocks are assumed to be zero for nonforest land use categories;

- the average transfer rate into DOM is assumed to equal out the average transfer rate of DOM for land that remains in the same category, so that the net stock change is zero; and

- for forestland converted to another land use, the net stock change is not zero, but default values for estimating DOM carbon stocks are provided.

Finally, countries can report different tiers for different pools and land use categories.

This paper investigates differences in carbon stock changes depending on the tier chosen for the 4 examples listed in the introduction.

\subsubsection{Accounting methods}

There are 2 fundamentally different yet equally valid approaches to estimating stock changes:

(1) the process-based approach, which estimates the net balance of additions to and removals from a carbon stock (gain-loss method); and (2) the stockbased approach, which estimates the difference in carbon stocks at 2 points in time (stock-difference method).

\section{Gain-loss method}

In the gain-loss method, annual changes in carbon stocks are estimated by summing the differences between the gains and losses in a carbon pool. Gains occur due to growth (increase of biomass) and due to transfers of carbon from another pool (e.g. transfer of carbon from the live biomass carbon pool to the DOM pool due to harvest or natural disturbances). Losses occur due to transfers of carbon from one pool to another (e.g. the carbon in the slash during a harvesting operation is a loss from the aboveground biomass pool) or other processes such as decay, burning or harvesting.

For each pool, the carbon stock change is calculated using the following equation:

$\Delta C=\Delta C_{G}-\Delta C_{L}$

where:

$\Delta C \quad$ annual change in carbon stocks in the pool, $\mathrm{tC} / \mathrm{yr}$

$\Delta C_{G} \quad$ annual gain of carbon in the pool, $\mathrm{tC} / \mathrm{yr}$

$\Delta C_{L} \quad$ annual loss of carbon from the pool, $\mathrm{tC} / \mathrm{yr}$

\section{Stock-difference method}

The stock-difference method can be used where carbon stocks in relevant pools are measured at 2 points in time to assess carbon stock changes. The following equation is applied:

$\Delta C=\frac{\left(C_{t 2}-C_{t 1}\right)}{\left(t_{2}-t_{1}\right)}$

where:

$\Delta C \quad$ annual change in carbon stocks in the pool, $\mathrm{tC} / \mathrm{yr}$

$C_{t 1} \quad$ carbon stocks in the pool at time $t_{1}, \mathrm{tC}$

$C_{t 1} \quad$ carbon stocks in the pool at time $t_{2}, \mathrm{tC}$

The two methods give essentially the same result in terms of emissions, but differ in terms of effort. 
For example, the gain-loss method does not estimate the actual biomass stocks, which has advantages in certain situations. For example, it is nearly impossible to apply the stock-difference method to soil carbon in peatland, but relatively straightforward to implement the gain-loss approach (Verchot personal communication). As these two methods are essentially identical, this paper does not analyse or comment on data differences between them.

\subsubsection{Assessing the potential of forest- based bioenergy for climate change mitigation}

To assess the potential of forest-based bioenergy for climate change mitigation, it is necessary to calculate the emissions and removals against a reference system and estimate any emissions that inadvertently occur outside the system boundary. Such emissions are known as 'leakage' in Clean Development Mechanism (CDM) terminology.

\section{Baseline or reference system}

The baseline or reference system is considered to be the emissions and land use that would occur in absence of the bioenergy activity. In the case of natural forest, such emissions may result from periodic natural disturbances such as fire or insect damage. In grasslands, the cause may be continued use as grazing land or perhaps slow natural regeneration of forest. Croplands could continue to be used for agricultural purposes, converted to grasslands or abandoned as degraded lands with slow natural regeneration of forest.

The baseline or reference system is project and site specific and there is no IPCC methodology for its incorporation. It is included below as part of each example.

\section{Indirect land use change and leakage}

Indirect land use change (iLUC) refers to land use change that occurs outside the system boundary because of the loss of a service that the land provided before the application of the bioenergy activity. A well-documented example of iLUC is the deforestation of Brazilian Amazon rainforest caused by the shift from corn production for animal feed to ethanol production in the United States (Fargione et al. 2008, Searchinger 2008). This loss of animal feed (not corn) caused an increase in the production of soy in Brazil and resulted in largescale deforestation.

In the CDM lexicon, emissions resulting from iLUC are a type of leakage. iLUC is potentially the largest source of leakage for many bioenergy activities but leakage should incorporate all emissions outside the project or system boundary that occur as a result of the activity.

To properly assess the potential of forest-based bioenergy for climate change mitigation, iLUC and leakage emissions should be considered. The emissions caused by the iLUC appear in the emission inventory of the country in which the iLUC occurs (if it is reporting), regardless of whether the land use change occurs in that country.

\section{Cyclic harvesting systems}

Permanence, or the potential for the loss of carbon stocks, is a perennial issue in LULUCF projects. Of interest here is a method for assessing the carbon stocks in forest systems that have cyclic harvesting. The 2006 IPCC Guidelines do not develop a methodology for this situation because the IPCC methodology is inventory based, i.e. all losses and gains are incorporated.

In an earlier IPCC publication (IPCC 2000), it was suggested that, for carbon stocks in forest systems with cyclic harvesting, the cycle average carbon stock is assumed for all cycles after the first cycle. During the first cycle the carbon stock changes between the reference carbon stock and the cycle average are included Although this suggestion simplifies the dynamics of cyclic harvesting systems, it creates accounting problems because of the need to know the cycle average carbon stock value a priori.

A more tenable and realistic approach to forest systems with cyclic harvesting is to use a moving average with the amount of time over which the 
average is estimated is equal to the cycle length. This is equivalent to assuming that the activity is evenly distributed over time; this is a reasonable assumption that is equivalent to assuming a constant flow of bioenergy feedstocks once the activity reaches maturity.

Figure 3 compares approaches to dealing with forest systems with cyclic harvesting. A moving-average approach has the following advantages over other approaches.

- It does not require a priori knowledge of the average biomass in a cycle.

- It is easy to calculate.

- It represents a realistic situation of even production of the bioenergy feedstock.

The disadvantage of the moving-average approach is that it is a trailing estimate and does not respond to changes in emissions or removals as quickly as the other approaches. This is a conservative approach if the activity includes an increase in carbon stocks.

\section{Timing of emissions}

The IPCC methodology is designed for annual recording of emissions and removals. To understand the total impact of an activity, we use the cumulative emissions over the first cycle (until the new system approximately reaches dynamic equilibrium). See Section 4.1 for more on the timing and time-value of emissions.

\subsection{EU Renewable Energy Directive}

The EU Renewable Energy Directive is designed in recognition that:

'control of European energy consumption and the increased use of energy from renewable sources, together with energy savings and increased energy efficiency, constitute important parts of the package of measures needed to reduce greenhouse gas emissions and comply with the Kyoto Protocol to the United Nations Framework Convention on Climate Change, and with further Community and international greenhouse gas emission reduction commitments beyond 2012.' (\$1)

After stating that:

'... [t] he lack of transparent rules and coordination between the different authorisation bodies has been shown to hinder the deployment of energy from renewable sources,' (\$41)

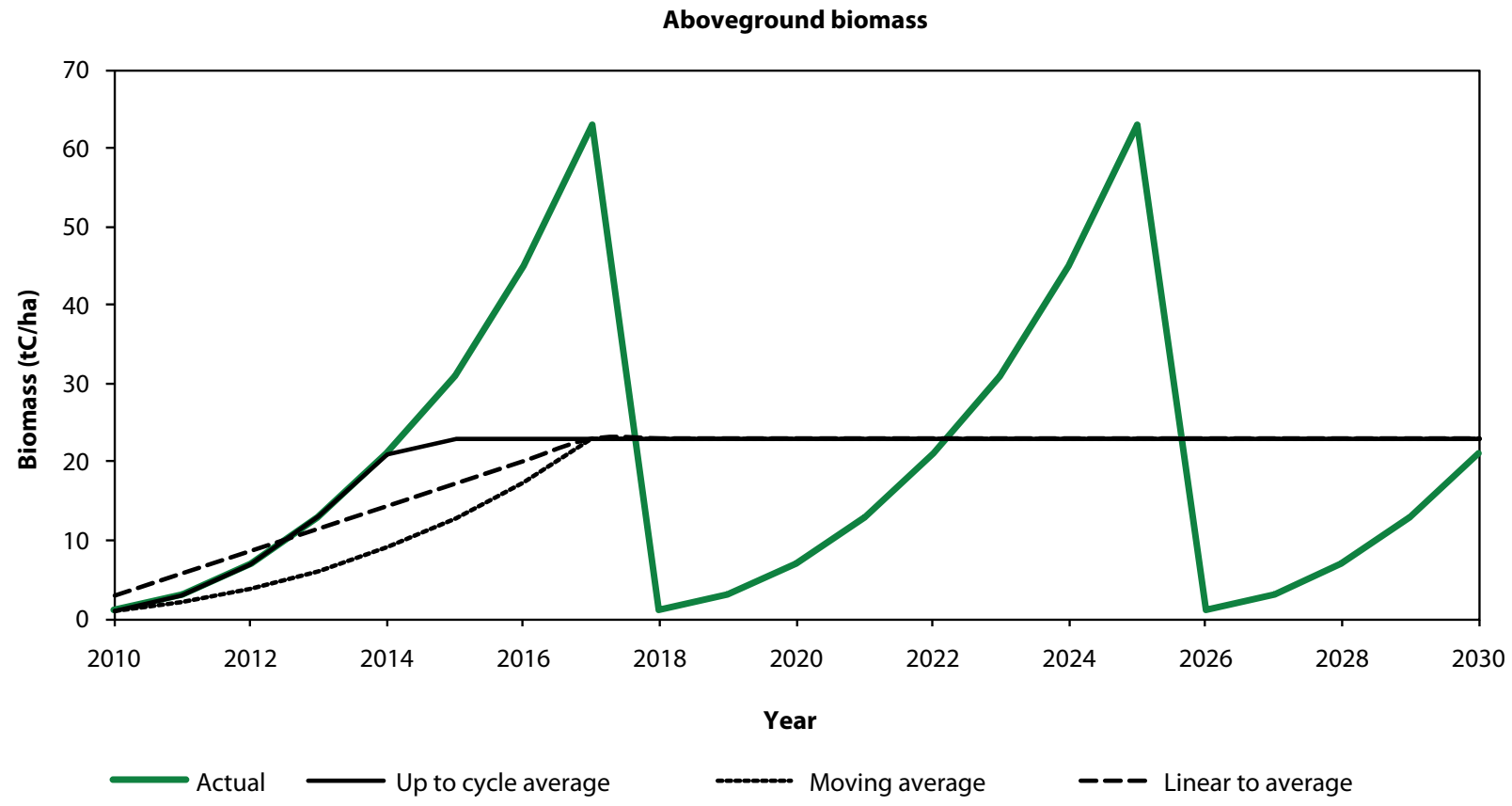

Figure 3. Comparison of approaches for dealing with forest systems with cyclic harvesting 
the EU Renewable Energy Directive finds that it is:

'... necessary to lay down clear rules for the calculation of greenhouse gas emissions from biofuels and bioliquids and their fossil fuel comparators.' (\$80)

It does so in a simplified manner on the grounds that:

'... economic operators should be able to use actual values for the carbon stocks associated with the reference land use and the land use after conversion. They should also be able to use standard values. The work of the Intergovernmental Panel on Climate Change is the appropriate basis for such standard values. That work is not currently expressed in a form that is immediately applicable by economic operators. The Commission should therefore produce guidance drawing on that work to serve as the basis for the calculation of carbon stock changes for the purposes of this Directive, including such changes to forested areas with a canopy cover of between 10 to $30 \%$, savannahs, scrublands and prairies.' (\$71)

In June 2010, the EU Commission released 3 documents related to land use change and biofuels designed to clarify issues in the EU Renewable Energy Directive. These documents are:

1. Communication on the practical implementation of the EU biofuels and bioliquids sustainability scheme and on counting rules for biofuels (European Union 2010a);

2. Communication on voluntary schemes and default values in the EU biofuels and bioliquids sustainability scheme (European Union 2010b); and

3. Commission decision on guidelines for the calculation of land carbon stocks for the purpose of Annex V of Directive 2009/28/EC (EU RED Guidelines). (European Union 2010c).

\subsubsection{Applicability}

To preserve areas of high biodiversity, the $E U$ Renewable Energy Directive limits the areas allowed for the production of biofuels and bioliquids. The following areas may not be used (Art. 17(3)): (a) primary forest and other wooded land, namely forest and other wooded land of native species, where there is no clearly visible indication of human activity and the ecological processes are not significantly disturbed;

(b) areas designated ... (i) for nature protection purposes; or (ii) for the protection of rare, threatened or endangered ecosystems or species...;

(c) highly biodiverse grassland.

Furthermore, to preserve areas of high carbon stock, the EU Renewable Energy Directive states that biofuel and bioliquid production is not allowed in areas that had the following status in January 2008 and did not have that status at the time the feedstocks were obtained (Art. 17(4)):

(a) wetlands...;

(b) continuously forested areas, namely land spanning more than one hectare with trees higher than five metres and a canopy cover of more than $30 \%$, or trees able to reach those thresholds in situ;

(c) land spanning more than one hectare with trees higher than five metres and a canopy cover of between $10 \%$ and $30 \%$, or trees able to reach those thresholds in situ, unless evidence is provided that the carbon stock of the area before and after conversion is such that, when the methodology laid down in part $\mathrm{C}$ of Annex $\mathrm{V}$ is applied, the conditions laid down in paragraph 2 of this Article would be fulfilled [i.e. unless the carbon stock losses are accounted for using the methodology].

It is important to note that the applicability conditions preclude the possibility of deforestation in the creation of biofuels and bioenergy under the EU Renewable Energy Directive. Nevertheless, we include this example in our discussion for comparison.

\subsubsection{Methodology}

The EU Renewable Energy Directive plus EU RED Guidelines are designed to estimate the emissions from the changes in carbon stocks due to land use change only. The very simple methodology is based 
on the 2006 IPCC Guidelines for Tier 1 calculation of land carbon stocks. It annualises the carbon stock changes caused by land use change over a 20year period; carbon stocks include both vegetation and soil. Thus, it is a stock-difference method. The methodology uses the following equation:

$e_{l}=\frac{\left(C S_{R}-C S_{A}\right) \times 3.664}{20 \times P}-e_{B}$

where:

$e_{l} \quad$ annualised greenhouse gas emissions from carbon stock change due to land use change (measured as mass of $\mathrm{CO}_{2}$-equivalent per unit biofuel energy)

$C S_{R} \quad$ the carbon stock per unit area associated with the reference land use (measured as mass of carbon per unit area, including both soil and vegetation). The reference land use is the land use in January 2008 or 20 years before the raw material was obtained, whichever was the later.

Vegetation includes above- and belowground living vegetation as well above- and belowground dead organic matter (dead wood and litter).

$C S_{A} \quad$ the carbon stock per unit area associated with the actual land use (measured as mass of carbon per unit area, including both soil and vegetation). This is taken as:

- in the case of loss of carbon stock: the estimated equilibrium carbon stock that the land will reach in its new use;

- in the case of carbon stock accumulation: the estimated carbon stock after 20 years or when the crop reaches maturity, whichever is earlier.

Vegetation includes above- and belowground living vegetation as well as above- and belowground DOM (dead wood and litter).

3.664 the quotient obtained by dividing the molecular weight of $\mathrm{CO}_{2}(44.010 \mathrm{~g} / \mathrm{mol})$ by the molecular weight of carbon $(12.011 \mathrm{~g} / \mathrm{mol})$

$P \quad$ the productivity of the crop (measured as biofuel or bioliquid energy per unit area per year) bonus of $29 \mathrm{~g} \mathrm{CO}_{2}$ eq/MJ biofuel or bioliquid if biomass is obtained from restored degraded land

For comparison with the IPCC methodologies, which use $\mathrm{tC} /$ year as the unit for emissions, we modify the EU Renewable Energy Directive methodology to:

$\Delta C=\frac{\left(C S_{R}-C S_{A}\right)}{20}$

Thus, the key difference between the EU Renewable Energy Directive and the other methodologies lies in the use of a period of annualisation of 20 years.

Furthermore, as we explain in Section 2.1.4 and reiterate in the examples in Section 3, the 2006 IPCC Guidelines use a tiered approach for the carbon accounting, in which Tier 1 does not include litter and dead wood, but Tiers 2 and 3 do. By contrast, the EU Renewable Energy Directive suggests that dead wood and litter play a minor role in carbon stock changes with the exception of conversion of closed forest to cropland or grassland (deforestation).

The EU RED Guidelines provide the following equations for the calculation of carbon stocks.

$C S_{i}=A \times\left(C_{V E G}+S O C\right)$

where:

A a factor scaling to the area concerned (ha per unit area)

$C S_{i} \quad$ the carbon stock per unit area associated with the land use (measured as mass of carbon per unit area, including both soil and vegetation)

$C_{V E G}$ the above- and belowground vegetation carbon stock (measured as mass of carbon per hectare)

SOC the soil organic carbon (measured as mass of carbon per ha)

and

$$
\begin{aligned}
C_{V E G}= & B_{A G B} \mathrm{x}(1+R) \times C F_{B}+D O M_{D W} \mathrm{x} \\
& C F_{D W}+D O M_{L I}+C F_{L I}
\end{aligned}
$$


where:

$C_{V E G}$ the above- and belowground vegetation carbon stock (measured as mass of carbon per ha)

$B_{A G B} \quad$ aboveground living biomass (measured as mass of dry matter per ha)

$R \quad$ ratio of belowground carbon stock in living biomass to aboveground carbon stock in living biomass

$C F_{B} \quad$ carbon fraction of dry matter in living biomass (measured as mass of carbon per mass of dry matter); default value $=0.47$

$D O M_{D W}$ mass of dead wood pool (measured as mass of dry matter per hectare)

$C F_{D W} \quad$ carbon fraction of dry matter in dead wood pool (measured as mass of carbon per mass of dry matter); default value $=$ 0.509

$D O M_{L I}$ mass of litter (measured as mass of dry matter per ha);

$C F_{L I} \quad$ carbon fraction of dry matter in litter (measured as mass of carbon per mass of dry matter); default value $=0.40$

However, equation 8 is seldom used because the $E U$ $R E D$ Guidelines advocate using default values that are included in tables within the document. ${ }^{10}$

There is no acknowledgement of carbon stocks in harvested wood products in solid waste disposal (SWD) sites in the EU Renewable Energy Directive.

\section{Baseline}

Because the emissions are estimated against a reference land use of 'January 2008 or 20 years before the raw material was obtained, whichever was the later', the EU Renewable Energy Directive assumes constant carbon stocks in the baseline. This means that in the absence of the project there is:

- no land use change; and

- no growth or removals of carbon stocks on the land.

\section{Indirect land use change and leakage}

The EU Renewable Energy Directive acknowledges that bioenergy activities may cause iLUC but does not propose a methodology to account for these emissions.

\section{Cyclic harvesting systems}

For cyclic harvesting systems such as cropland, perennial crops and forest plantations, the $E U$ Renewable Energy Directive adopts the time average of above- and belowground living biomass during the production cycle or, in the case of carbon stock accumulations, the stock after 20 years or the first cycle, whichever is earlier.

\section{Timing of emissions}

As previously mentioned, the EU Renewable Energy Directive amortises the total carbon stock change over the first 20 years.

\subsection{Clean Development Mechanism methodologies}

The CDM only includes afforestation and reforestation (A/R) in the Kyoto Protocol. For these activities, the methodologies apply the IPCC methodology, with the additional conservative simplification of ignoring pools that can be demonstrated to have carbon stocks that are increasing faster or decreasing more slowly with the project than without the project.

\section{Baseline}

The CDM methodologies determine the baseline and demonstrate the additionality of a project using a tool developed by the CDM Executive Board (2007). The tool is used to identify scenarios for land use in the future (one of which must be the activity without CDM funding) and then to identify barriers to the scenarios. If a single scenario remains without barriers, then it is the baseline. If more than one scenario remains without barriers, then a financial analysis is performed; the baseline is the scenario with the best financial performance.

To date, of the projects submitted for validation, the continuation of the present land use is considered the baseline, which is similar to the $E U$ 
Renewable Energy Directive. The majority of CDM methodologies ignore increases in carbon stocks in the baseline by demonstrating that stocks have not increased or will not increase due to ecological factors such as degradation of lands, competition with grasses, persistent grazing by livestock or a high frequency of fires. However, some of the CDM methodologies do include increases in carbon stocks in the baseline.

\section{Indirect land use change and leakage}

All CDM methodologies must consider the possibility of leakage. They limit the possibility of leakage through applicability conditions or ignore leakage if it is considered insignificant.

\section{Cyclic harvesting systems}

The CDM methodologies differ from the IPCC methodology in that they assume that removals by forests are temporary: either they are short-term temporary removals (tCERs) that are assumed to be re-emitted after 5 years unless monitoring proves that sequestration still exists, or they are long-term temporary removals (lCERs). lCERs are accrued incrementally and must be replaced if lost due to harvesting or if other disturbances occur.

\section{Timing of emissions}

The CDM methodologies involve annual recording of emissions that are averaged over 5-year periods. This is because monitoring of the carbon stock is carried out every 5 years.

\subsection{Voluntary Carbon Standard methodologies}

The Voluntary Carbon Standard (VCS) is an organisation outside the UNFCCC that is designing methodologies for use for non-compliant, voluntary emission reductions. The VCS builds on CDM methodologies for $\mathrm{A} / \mathrm{R}$, and the first non- $\mathrm{A} / \mathrm{R}$ methodologies were submitted for public comment in 2010 .

The VCS includes a baseline, iLUC and leakage and uses an 'up to the cycle average' approach for handling cyclic harvesting systems. 


\section{Examples}

\subsection{Reforestation: Grassland to forest: South Africa - short rotation forestry}

\subsubsection{Description}

In this example, we investigate the carbon stock changes when grassland in South Africa is converted to Acacia mearnsii (black wattle) for the purpose of creating biomass for combustion. It is assumed that the plantation is near Pietermaritzburg $\left(29^{\circ} 36 \mathrm{~S} 30^{\circ} 26^{\prime} \mathrm{E}\right.$, average temperature $18.5^{\circ}$, annual rainfall $844 \mathrm{~cm}$; South African Weather Service 2009).

A typical harvest rotation for Acacia mearnsii is 10 years. Therefore, the forest or plantation area is 10 ha with 1 ha planted each year for 10 years so that there is a constant biomass output at harvest in year 10. This is the same as the moving average approach mentioned earlier. We assume that the plantation is planted on moderately degraded grassland. The growth and harvesting parameters are given in Section 5.1.

\subsubsection{IPCC methodology details}

\section{Tier 1}

In Tier 1, the stock changes for above- and belowground biomass are calculated using the gain-loss method (equation 3) with the default parameters from 2006 IPCC Guidelines. The loss of original biomass at the start of the activity is ignored (i.e. the grass). For litter, a default amount of biomass that accumulates over 20 years is assumed. This is converted to an annual litter gain. For dead wood, no accumulation is assumed and for soil the initial biomass and biomass after 20 years are estimated based on default values of soil type, climate, land use management and input. In this example, the degraded grassland is estimated to have $97 \%$ of the soil organic carbon (SOC) of the forest.

\section{Tier 2}

Tier 2 uses national- or species-specific data where available. Furthermore, the existing biomass is assumed to be lost in the first year. This is significantly different from the Tier 1 calculation.

The aboveground live biomass is estimated using a yield curve that is curvilinear and we used a middle range site index yield curve $(\mathrm{SI}=16.6)$ that had a slightly lower mean annual increment, $8.9 \mathrm{t}$ dry matter (d.m.), at harvest age.

Litter and dead wood also are estimated using species-specific data. Dead wood tends to be a very small component of the aboveground biomass (0.4\%) (Winckler Caldeira 2002) and can be ignored. We were not able to determine typical values for carbon stocks in litter and soil under an Acacia mearnsii plantation in South Africa. A Tier 1 approach will be used for these pools. 
The soil organic carbon is estimated using the Tier 1 approach for reducing the stocks on the degraded grassland using an average measured SOC value for South Africa (Zinke 1986) for the reference value.

\section{Tier 3}

In Tier 3 we use the full carbon flow model, GORCAM (the same version as that used in the ENCOFOR project; see Footnote 2). It includes species-specific information for the yield curve (as discussed above), foliage and branch components (Winckler Caldeira et al 2002), grassland parameters and initial SOC stocks. Decay of litter and dead wood are estimated using a temperature, precipitation and litter quality model. The SOC decay parameters are calculated by assuming that the grassland is at a steady state with the starting measured SOC value.

At harvest we assume that the foliage remains on site as litter and that Acacia coppices (i.e. the roots do not die and enter the dead wood and litter pools).

\section{EU Renewable Energy Directive}

Using the EU Renewable Energy Directive default tables in the EU RED Guidelines (European Union 2010c), the reference carbon stocks, $C S_{R}$, would be $4.4 \mathrm{tC} /$ ha (Table 3: Tropical dry forest) and the actual carbon stocks, $C S_{A}$, would be $9.0 \mathrm{tC} / \mathrm{ha}$ (Table 18: Tropical dry forest, Africa broadleaf $\leq$ 20 years).

\subsubsection{Results}

The results of the analysis are shown in Table 2. Figure 4 displays the annual total stock changes under the 4 accounting methodologies. A comparison of biomass profiles for the stand and the averaged forest (10 stands, 1 stand planted every year) is shown in Figure 5.

Table 2 summarises the cumulative carbon stock changes under the 4 accounting methods. The Tier 1 method results in the highest aboveground biomass (10 times $10 \mathrm{t}$ d.m./year for a total of $100 \mathrm{t}$ d.m. at maturity). When converted to carbon and averaged over the rotation, this is equivalent to

Annual total carbon stock changes

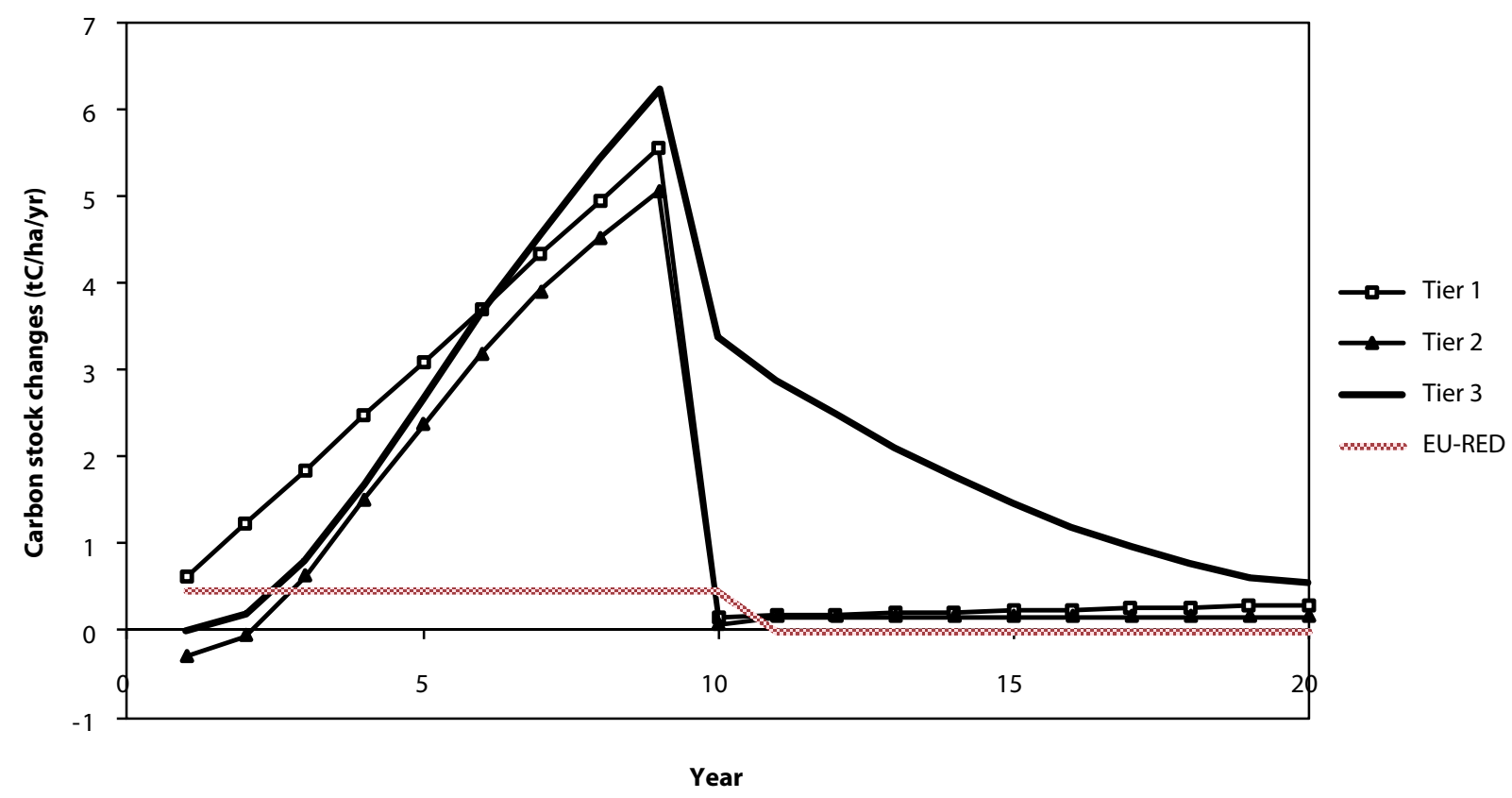

Figure 4. Reforestation example: A comparison of the total carbon stock changes by year under the 4 accounting methods 
Table 2. Reforestation example: Comparison of the cumulative carbon stock changes in the first rotation under the 4 accounting methods

\begin{tabular}{|c|c|c|c|c|}
\hline \multirow{2}{*}{ Pool } & \multicolumn{3}{|c|}{ IPCC } & \multirow{2}{*}{ EU Renewable Energy Directive } \\
\hline & Tier 1 & Tier 2 & Tier 3 & \\
\hline Aboveground biomass (tC/ha) & 21.2 & 17.3 & 17.7 & \\
\hline Belowground biomass (tC/ha) & 5.9 & 3.6 & 4.4 & 4.6 \\
\hline Dead wood (tC/ha) & & & 0.2 & \\
\hline Litter (tC/ha) & 0.5 & -0.4 & 4.2 & \\
\hline Soil (tC/ha) & 0.2 & 0.3 & -1.3 & 0.2 \\
\hline \multicolumn{5}{|l|}{ Harvested wood products (tC/ha) } \\
\hline Total (tC/ha) & 27.7 & 20.8 & 25.2 & 4.8 \\
\hline
\end{tabular}

\section{Stand}

Tier 1

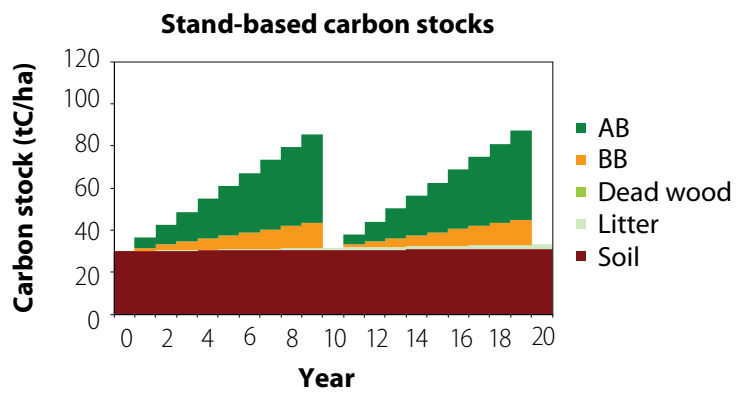

Tier 2

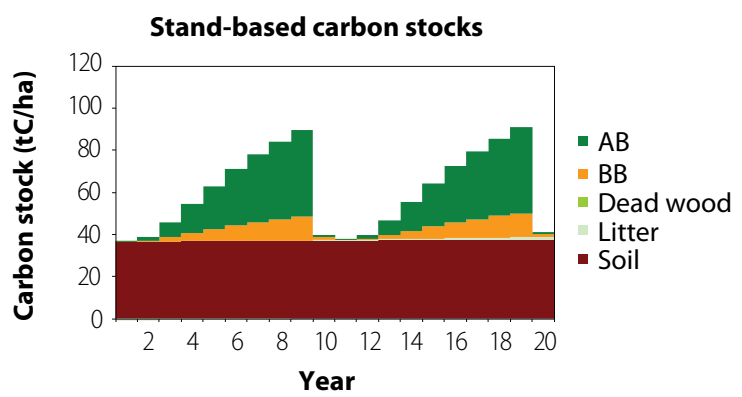

Tier 3

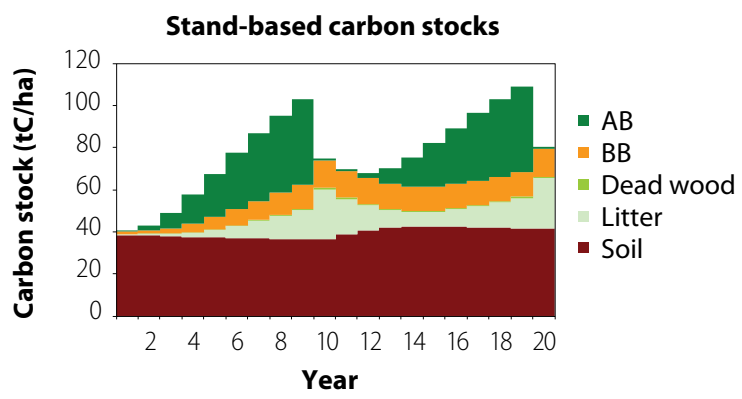

\section{Forest}

Tier 1

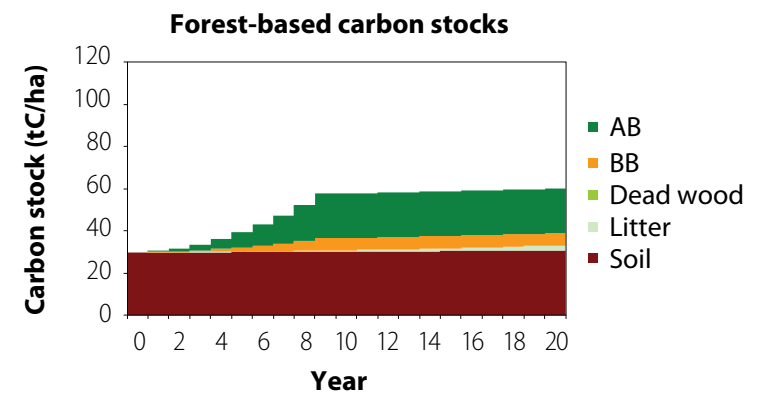

Tier 2

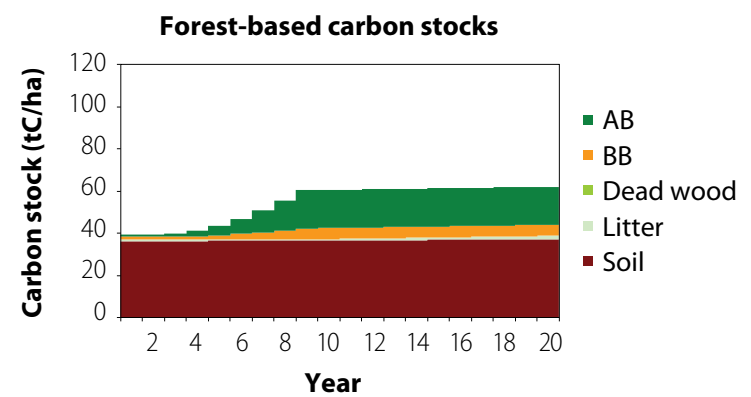

Tier 3

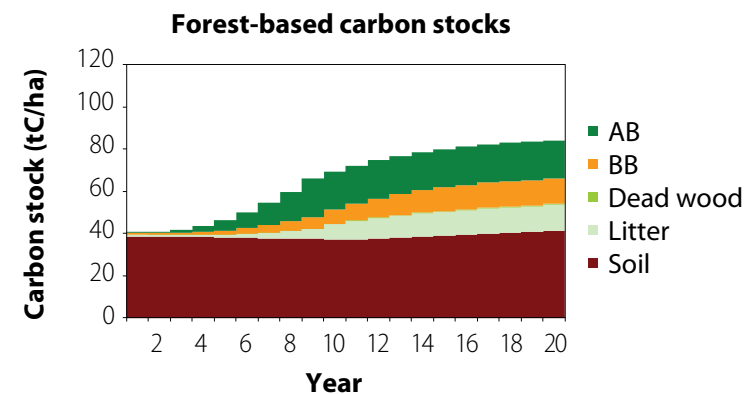

Figure 5. Reforestation example: Stand and 'averaged forest' biomass 
$21.2 \mathrm{tC} / \mathrm{ha}$. This should be compared with the value in the EU RED Guidelines of $9.0 \mathrm{tC} /$ ha. Furthermore, the Tier 1 methodology ignores the loss of grassland biomass. For these reasons, even though the EU RED Guidelines are also Tier 1, they give a much smaller estimate of carbon sequestration than the Tier 1 approach.

The belowground biomass is significantly higher when using the Tier 3 method than when using the other methods because we have assumed that Acacia mearnsii coppices. Only Tier 3 includes dead wood, but this is a very small fraction of the cumulated carbon stock changes. Tier 3 has the largest cumulative carbon stock changes in the litter and soil because this is the most realistic model.

The large sequestration in the litter pool and the sequestration that occurs in the second rotation are apparent in the difference in accumulated carbon stocks between the Tier 3 and EU Renewable Energy Directive approaches. This is also evident in Figure 4. As each stand comes to maturity after 10 years, the EU Renewable Energy Directive approach is linearised over 10 years (and not 20 years).

The judgment of which of the accounting methodologies that should be recommended in this example depends on one's viewpoint. Tier 3 is the most complicated and includes the most pools. The other methodologies underestimate the cumulated carbon stock changes and are thus conservative with respect to $\mathrm{CO}_{2}$ removed from the atmosphere and climate change mitigation. However, from the viewpoint of environmental integrity, they are just as comprehensive as the Tier 3 methodology. For the EU Renewable Energy Directive, a conservative estimate is appropriate. However, as seen in Table 2, it is very conservative. For a project in a developing country using CDM to fund the project, a conservative estimate will reduce project funding and may mean that the project does not proceed.

\subsection{Forest degradation: Unmanaged forests to plantations: Malaysia - palm plantations on native forest}

\subsubsection{Description}

In this example, we investigate the carbon stock changes when native forests are harvested to make palm plantations for oil. This is an example of 'forestland remaining forestland'.

A typical palm oil plantation must be renewed after 30 years. Therefore, in this example, the forest or plantation area is 30 ha with 1 ha of native forest cleared and planted each year for 30 years. We assume that the biomass during clearing is burnt or used as wood fuel. This is a conservative assumption because some harvested wood products (HWP) could be created, but as the IPCC methodology for carbon storage in HWP has not been finalised, we ignore it here. We also assume that the native forest is situated on high-activity clay soil. The growth and harvesting parameters are given in Section 5.2.

\subsubsection{IPCC methodology details}

\section{Tier 1}

The Tier 1 methodology for 'forestland remaining forestland' is very simple. Dead wood and litter are assumed to be constant, and above- and belowground biomass are calculated using default factors from the 2006 IPCC Guidelines. The SOC is also assumed to remain constant.

\section{Tier 2}

Tier 2 uses national- or species-specific data where available. The aboveground biomass in the native forest is much lower ${ }^{11}$ than the value from the 2006 IPCC Guidelines. The aboveground live biomass of a palm stand is estimated using an appropriate yield curve. 


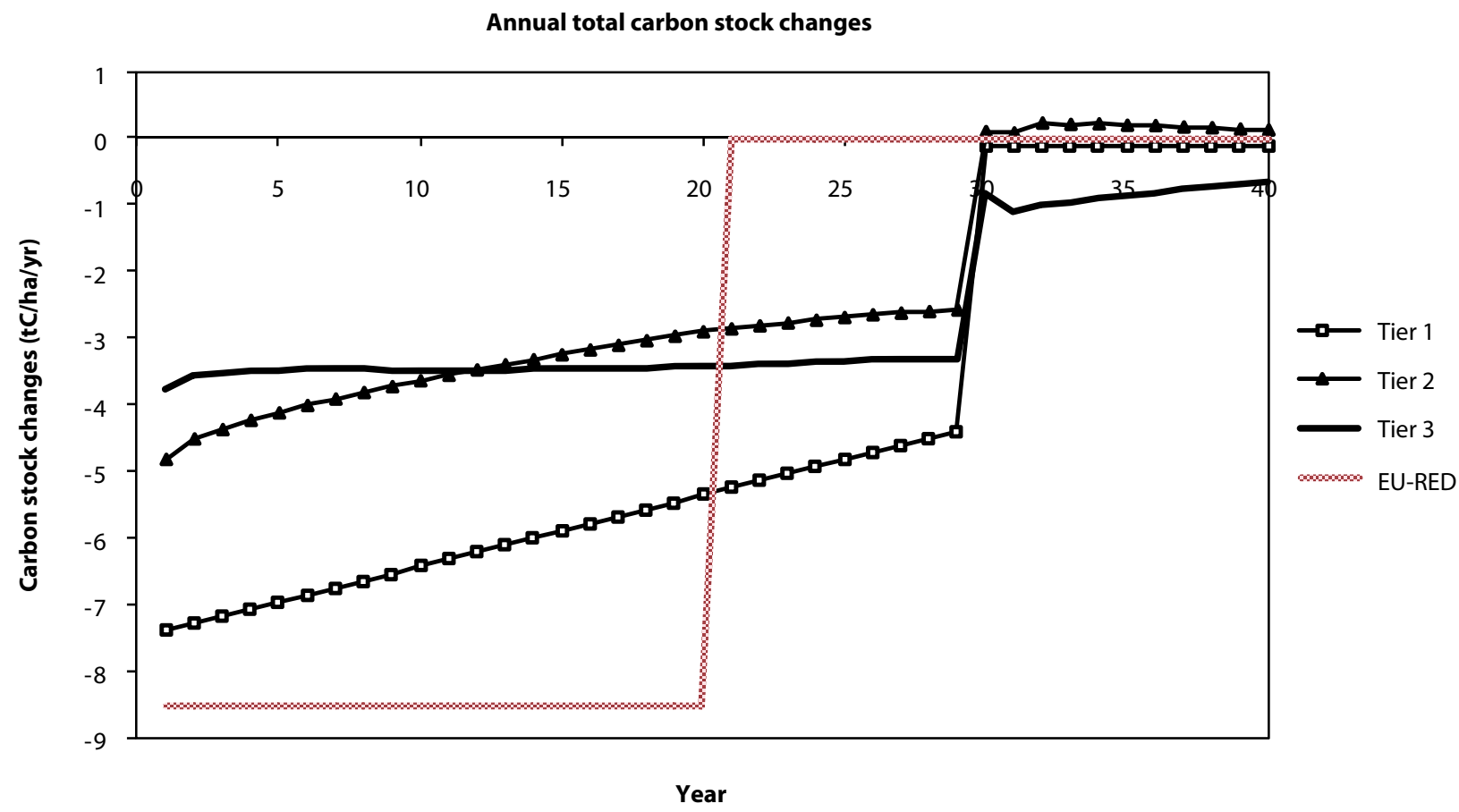

Figure 6. Forest degradation example: Comparison of the total carbon stock changes by year under the 4 accounting methods

Litter is also estimated using species-specific data. We have assumed a linear transition over 20 years for litter.

The SOC is estimated using the Tier 1 approach (linear transition of 20 years). It uses the value from the 2006 IPCC Guidelines for SOC in the native forest, but a measured value for SOC in a palm plantation after 20 years.

\section{Tier 3}

In Tier 3, we use the full carbon flow model, GORCAM (version used in the ENCOFOR project; see Footnote 2). The model includes species-specific information for the yield curve (discussed above in Tier 2), foliage and branch components and initial SOC stocks. Decay of litter and dead wood are estimated using a temperature, precipitation and litter quality model. The SOC decay parameters are calculated by assuming that the native forest is at a steady state with the starting measured SOC value.
During clearing, we assume that all foliage remains on site, but all woody biomass is burnt or used for wood fuel (Figure 7). The coarse woody roots become dead wood and decay, causing a temporary increase in the SOC.

At plantation replacement, we assume that the foliage remains on site as litter and that palms do not coppice. This results in a large increase in dead wood due to the dead coarse woody roots.

\section{EU Renewable Energy Directive}

As the EU Renewable Energy Directive applies only to emissions from land use change, and this example is not land use change but 'forest remaining forest', the EU Renewable Energy Directive result would be zero (i.e. no carbon stock loss). Nevertheless, we proceed with a calculation using the default tables in EU RED Guidelines; (European Union 2010c). From these, the reference carbon stocks, $C S_{R}$, would be $230 \mathrm{tC} /$ ha (Table 17: Tropical rainforest, Asia [insular]) and the actual carbon stocks, $C S_{A}$, would be $60 \mathrm{tC} / \mathrm{ha}$ (Table 12: Oil palm). 
Stand

Tier 1

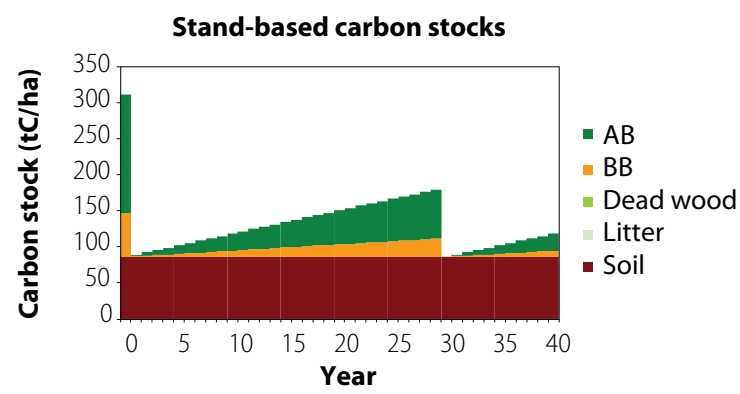

Tier 2

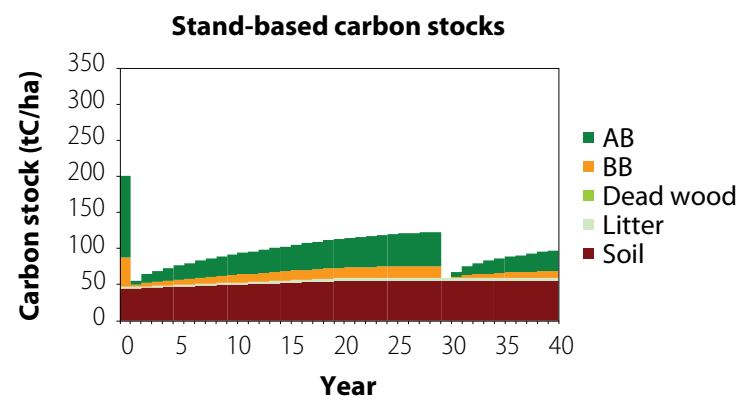

Tier 3

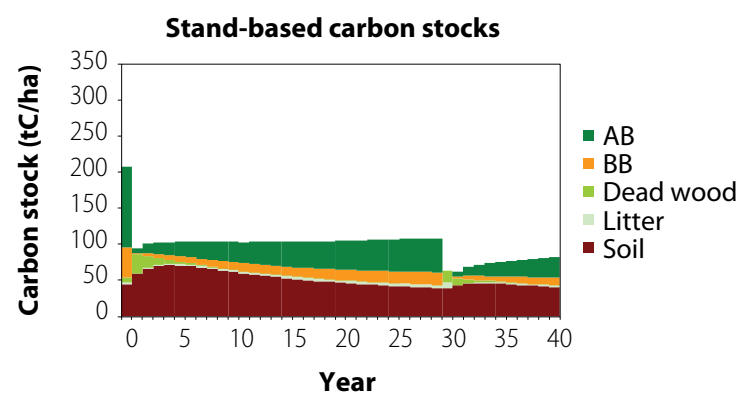

\section{Forest}

Tier 1

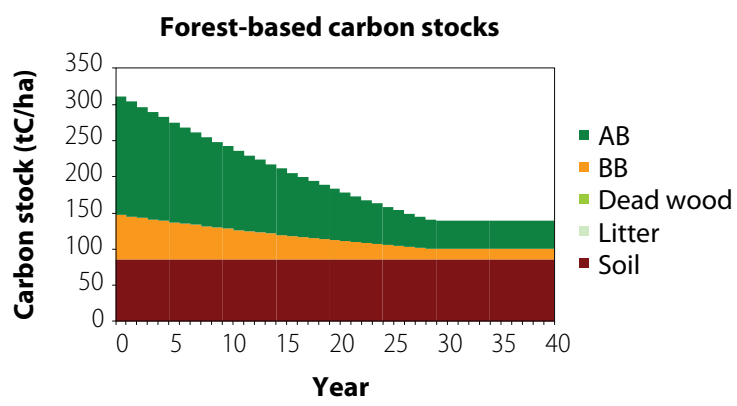

Tier 2

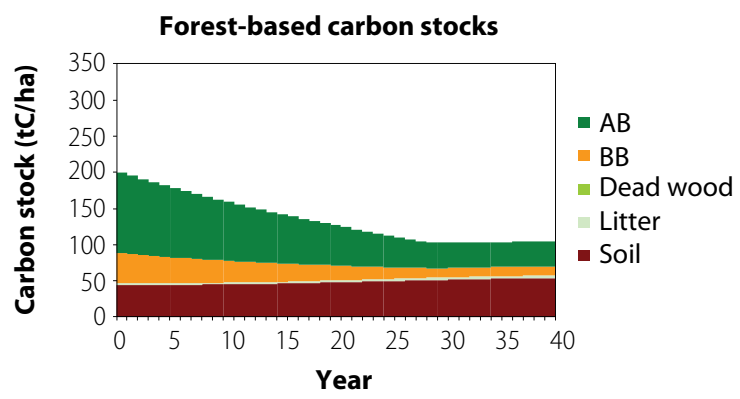

Tier 3

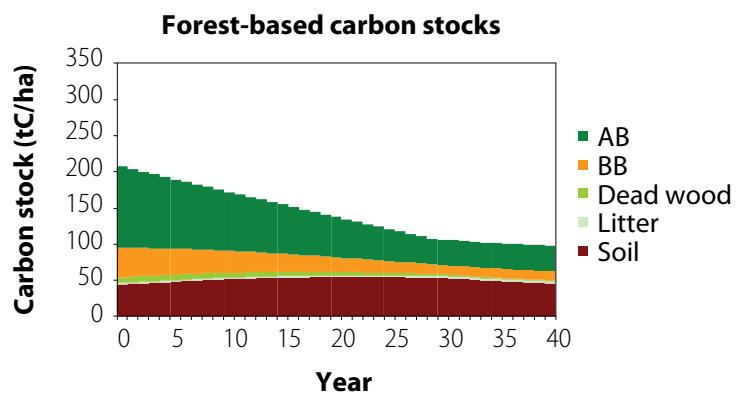

Figure 7. Forest degradation example: Stand and 'averaged forest' biomass

\subsubsection{Results}

The results of the analysis are shown in Table 3, which summarises the cumulative carbon stock changes under the four accounting methods. The Tier 1 estimate results in the largest loss of carbon stocks in living biomass, followed by the $E U$ Renewable Energy Directive estimate. This is due to the higher assumed biomass in the native forest in these 2 estimates than in the Tier 2 and Tier 3 estimates. The inclusion of dead wood (Tier 3 ) and litter (Tiers 2 and 3 ) makes very little difference to the total estimate of carbon stock losses because of the high decomposition rates in warm tropical forests. This contradicts the statement in the $E U$ RED Guidelines ( $\$ 4$ ) that DOM should be taken into consideration for closed forests. In the Tier 2 and Tier 3 estimates, the SOC actually has a small gain of biomass over the first rotation, as a result of the large amount of roots that become belowground dead wood after clearing. As this decays, it causes a temporary increase in SOC during the first plantation rotation, but the SOC continues to decline in the second rotation (Figure 7). 
Table 3. Forest degradation example: Comparison of the cumulative carbon stock changes in the first rotation under the 4 accounting methods

\begin{tabular}{|c|c|c|c|c|}
\hline \multirow{2}{*}{ Pool } & \multicolumn{3}{|c|}{ IPCC } & \multirow{2}{*}{ EU Renewable Energy Directive } \\
\hline & Tier 1 & Tier 2 & Tier 3 & \\
\hline Aboveground biomass (tC/ha) & -124.9 & -77.1 & -77.1 & \\
\hline Belowground biomass (tC/ha) & -46.2 & -28.5 & -28.5 & -170.0 \\
\hline Dead wood (tC/ha) & & & -4.5 & \\
\hline Litter (tC/ha) & & 1.0 & 0.6 & \\
\hline Soil (tC/ha) & 0.0 & 6.9 & 9.4 & 0.0 \\
\hline \multicolumn{5}{|l|}{ Harvested wood products (tC/ha) } \\
\hline Total (tC/ha) & -171.2 & -97.8 & -100.1 & -170.0 \\
\hline
\end{tabular}

Note: In a literal interpretation of the EU Renewable Energy Directive, there would be no change of carbon stocks, because this example does not feature any land use change.

Figure 6 displays the annual total stock changes under the 4 accounting methodologies. The $E U$ Renewable Energy Directive, using the default values, results in the same carbon stock loss as the Tier 1 estimate, but it is all accounted for during the first 20 years rather than over a rotation. Given the use of the default values, there is no reason why the carbon stock loss during the conversion to plantation should not be estimated in the EU Renewable Energy Directive even though there is no land use change.

\subsection{Forest management: Use of harvest residuals: Austria - collection of thinning and harvest residuals}

\subsubsection{Description}

In this example, we investigate the carbon stock changes when residuals (branches and tops) from thinning and harvesting operations are used as bioenergy. This example is important because using residuals is one method of increasing the efficiency of biomass use. Hence, the system creates a source of bioenergy without competing with other uses of the biomass. Simply using the stem biomass from thinning and harvesting for bioenergy may cause indirect land use change if the biomass has other uses (e.g. pulp or timber). Furthermore, diverting the stem biomass from the uses will also cause a decrease in the carbon stocks in HWP and SWD sites.

The example is a typical stand of Norway spruce (Picea abies) in the Austrian Alps near Bruck an der Mur. ${ }^{12}$ The stand has a rotation period of 90 years. As the stand grows, it is thinned periodically. Normally the residuals (i.e. branches and tops) from thinning and harvesting are left on the site, but in the future, as the demand for biomass for bioenergy grows, the woody portion may be removed from the site. The foliage will be left on site as it is important for the nutrient cycle. The growth and harvesting parameters are given in Section 5.3.

\subsubsection{PCC methodology details}

\section{Tier 1}

The Tier 1 methodology for 'forestland remaining forestland' is very simple: dead wood and litter are assumed to be constant, and above- and belowground biomass are calculated using default factors from the 2006 IPCC Guidelines. The SOC is also assumed to remain constant. The Tier 1 approach cannot estimate the carbon stock changes for this example. 


\section{Tier 2 and Tier 3}

The Tier 2 and Tier 3 accounting methodologies are identical for dead wood and litter for 'forestland remaining forestland'. The changes in DOM for both options are data intensive and require field measurements and models for their implementation. They are dependent on the amount of DOM produced annually and left after disturbances and on the rate of decay of DOM. The Tier 2 estimation requires national data on average proportions of carbon left after disturbances while the Tier 3 estimation uses species- and regionaldependent values. Both methods should use vegetation type and other factors that determine the time required for litter and dead wood pools to reach the steady state.

For the purposes of this report, we assume there is no difference between the Tier 2 and Tier 3 approaches. Both will be estimated using a modelled approach.

\section{EU Renewable Energy Directive}

As the EU Renewable Energy Directive applies only to emissions from land use change, and this example is not land use change but forest remaining forest, the EU Renewable Energy Directive result would be zero (i.e. no carbon stock loss). In contrast to the previous example, however, using the default factors from the EU Guidelines also results in zero because $\mathrm{C}_{\mathrm{VEG}}$ would be the same for both reference and actual cases.

\subsubsection{Results}

The comparison of the 4 accounting methodologies is summarised in Table 4. The Tier 1 calculation produces no changes in carbon stocks even though dead wood for bioenergy is being removed from the forest. The Tier 2/3 methodology based on modelling has a decrease in dead wood carbon stock and a corresponding decrease in SOC because some of the DOM enters the soil pool.

Because the EU Renewable Energy Directive ignores the changes in carbon stocks in DOM (dead wood and litter), it completely underestimates the emissions from the use of harvest residuals.

Figure 8 shows the annual stock changes for a forest that switches to using harvest residuals. Even if the EU Renewable Energy Directive did include carbon stock changes in dead wood and litter, the 20 -year estimate accounts for only $56 \%$ of the total carbon stock changes that occur in the forest $(6.9 \mathrm{tC} / \mathrm{ha})$. Therefore, not only are the pools ignored, but also the 20 -year estimate is a poor choice.

Figure 9 shows the modelled net carbon stocks for both the stand and the 'averaged forest'.

Table 4. Use of harvest residuals example: Comparison of the cumulative carbon stock changes in the first rotation years under the 4 accounting methods

\begin{tabular}{lccc}
\hline \multicolumn{1}{c}{ Pool } & \multicolumn{2}{c}{ IPCC } & EU Renewable Energy Directive \\
& Tier 1 & Tier 2 and Tier 3 & \\
Aboveground biomass $(\mathrm{tC} / \mathrm{ha})$ & 0.0 & 0.0 & 0.0 \\
Belowground biomass (tC/ha) & 0.0 & 0.0 & \\
Dead wood (tC/ha) & 0.0 & -5.0 & 0.0 \\
Litter (tC/ha) & 0.0 & 0.0 & \\
Soil (tC/ha) & 0.0 & -1.8 & 0.0 \\
Harvested wood products (tC/ha) & & & \\
Total (tC/ha) & 0.0 & -6.9 & \\
\hline
\end{tabular}




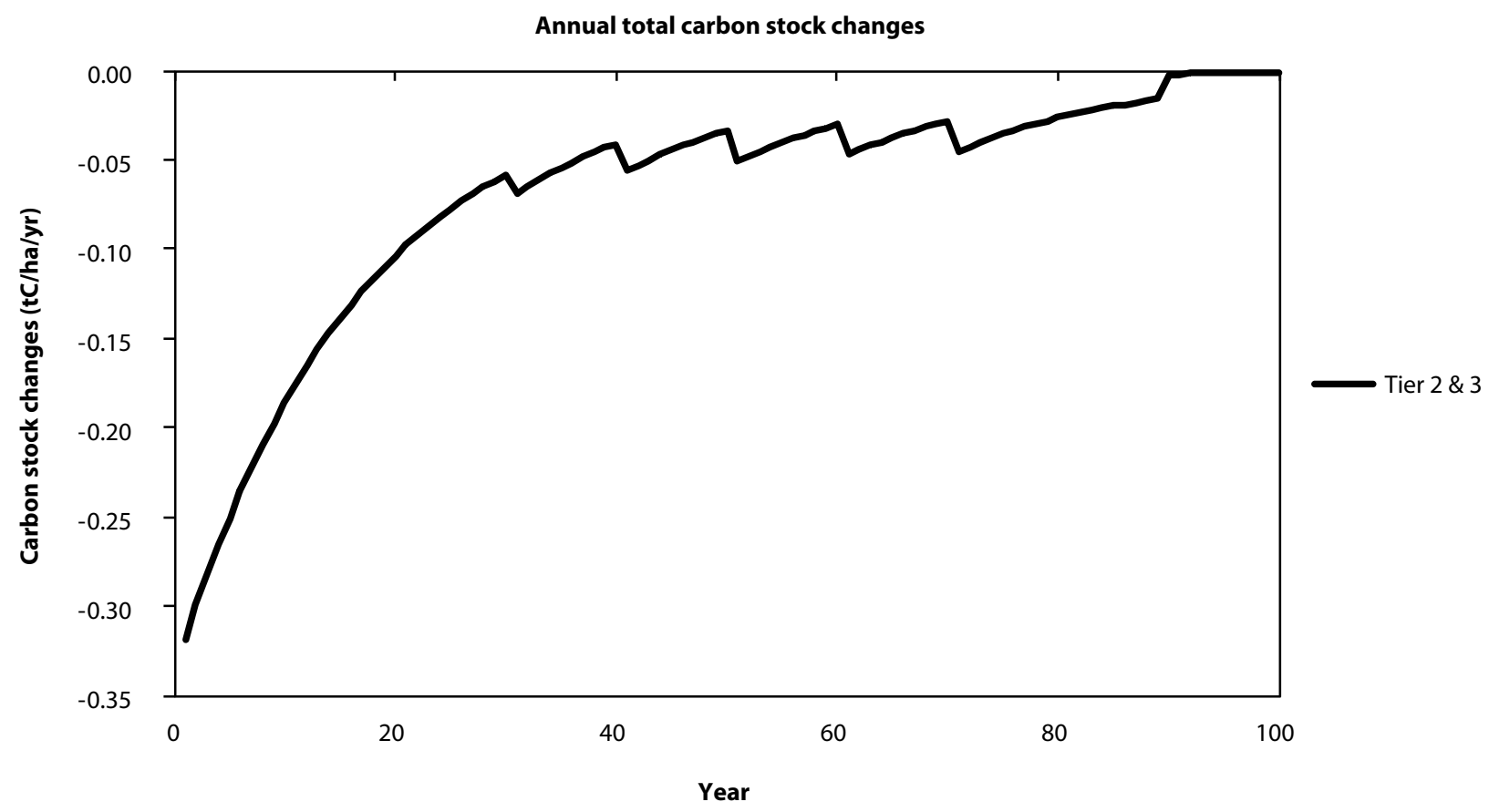

Figure 8. Use of harvest residuals example: Comparison of the total carbon stock changes by year under the 4 accounting methods

\section{Stand}

Tier 2 and Tier 3

Stand-based net carbon stocks

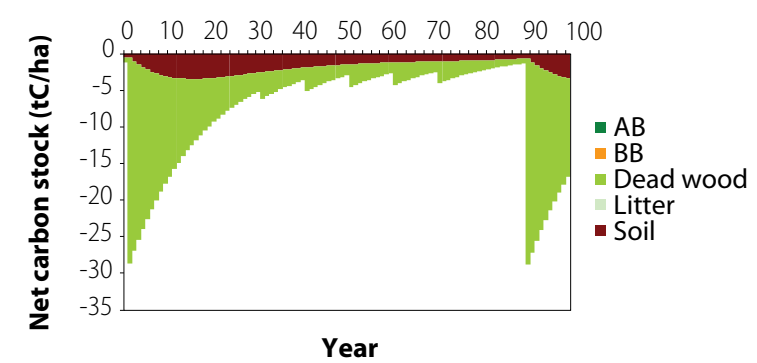

Forest

Tier 2 and Tier 3

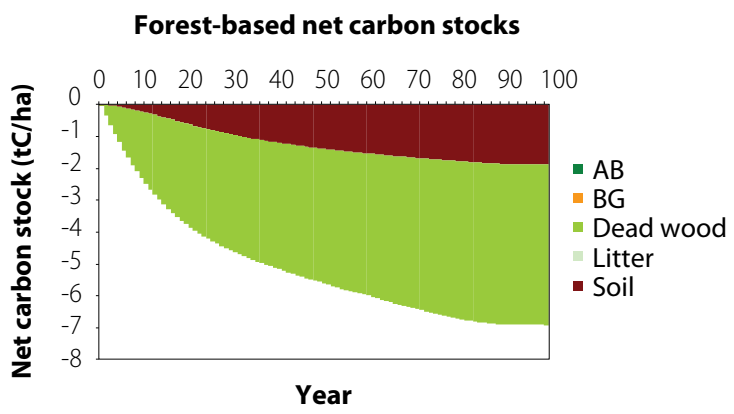

Figure 9. Use of harvest residuals example: Stand and 'averaged forest' biomass

\subsection{Deforestation: Forests to cropland: Mexico - a mixed pine/oak forest converted to cornfield}

\subsubsection{Description}

In the 4th and final case, we investigate the difference in accounting methods for a deforestation example from southern Mexico. A forest of mixed oak/pine is converted to a cornfield and the corn is used for ethanol production. During the conversion, as much woody biomass as possible is removed from the site. The remaining woody biomass and litter are burnt. Therefore, there is no increase in aboveground DOM during conversion. After conversion, the field produces, on average, $12 \mathrm{t}$ biomass/ ha and $80 \%$ of crop residuals are burnt. 
The biomass and crop parameters are given in Section 5.4.

\subsubsection{IPCC methodology details}

\section{Tier 1}

In the Tier 1 IPCC methodology, the change in carbon stocks in biomass is equal to the growth of woody biomass on the land after conversion minus all original biomass stocks. It is assumed that biomass immediately after conversion is zero or, equivalently, all carbon in biomass removed is lost to the atmosphere through burning or instantaneous decay processes either on-site or off-site.

The Tier 1 methodology for SOC is a linear transition from an initial value to a final value. The SOC amounts are calculated using the 2006 IPCC Guidelines default soil methodology, in which a reference value (for native vegetation) is reduced by factors that depend on land use, management and amount of inputs.

Values for biomass are drawn from default values.

\section{Tier 2}

The Tier 2 methodology is similar to Tier 1 except that there can be carbon stocks in dead wood and litter after conversion. Generally, it is assumed that dead wood on croplands is zero, but crop residuals may remain after harvest. The DOM pools lose carbon stocks in a linear manner throughout a chosen transition period (we chose a 20-year transition period). SOC stock changes are calculated in the same way as for Tier 1 .

In Tier 2, nationally appropriate values are used wherever possible.

\section{Tier 3}

Tier 3 uses a full carbon flow model or data sets to estimate the change in carbon stocks in all pools during conversion from forest to cropland. We use a version of GORCAM for this model. It uses speciesspecific information for the yield curve, foliage and branch components and transfer rates between pools. Decay of litter and dead wood are estimated using a temperature, precipitation and litter quality model. The initial dead wood, litter and SOC biomass is estimated by assuming that the forest, pre-conversion, is in the steady state.

\section{EU Renewable Energy Directive}

Using the EU Renewable Energy Directive default tables in the EU RED Guidelines, the reference carbon stocks, $C S_{R}$, would be $131 \mathrm{tC} / \mathrm{ha}$ (Table 17: Tropical dry forest, North and South America) and the actual carbon stocks, $C S_{A}$, would be $0 \mathrm{tC} / \mathrm{ha}$ (Table 9).

Table 5. Deforestation example: Comparison of the cumulative carbon stock changes after 20 years under the 4 accounting methods

\begin{tabular}{lrrrc}
\hline \multicolumn{1}{c}{ Pool } & \multicolumn{3}{c}{ IPCC } & EU Renewable Energy Directive \\
& Tier 1 & Tier 2 & Tier 3 & -131.0 \\
Aboveground biomass (tC/ha) & -98.7 & -168.9 & -168.9 & \\
Belowground biomass (tC/ha) & -27.6 & -47.3 & -47.3 & \\
Dead wood (tC/ha) & -2.1 & -12.8 & -12.8 & \\
Litter (tC/ha) & -8.6 & -21.0 & -21.0 & -15.7 \\
Soil (tC/ha) & -15.7 & -20.9 & -20.9 & \\
Harvested wood products (tC/ha) & & & & -146.7 \\
Total (tC/ha) & -152.7 & -270.8 & -270.8 & \\
\hline
\end{tabular}




\subsubsection{Results}

As this example does not include a system, before or after conversion, that has a cyclic component, we do not need to make the 'averaged forest' assumption. Instead, we base our analysis on the modelled stand response only (Figure 11). The comparison of the 4 accounting methodologies is summarised in Table 5.

Tier 1 underestimates the carbon stock changes from the deforestation because the default values for the aboveground biomass are $58 \%$ of the species-specific Tier 3 value. For the same reason, the amounts of belowground biomass (roots) and dead wood are also much lower than the Tier 3 estimate.
The Tier 2 and Tier 3 methodologies are identical over the 20 years. In this example, another $15.5 \mathrm{tC} / \mathrm{ha}$ of emissions occurs in the Tier 3 methodology between the $20^{\text {th }}$ and the $40^{\text {th }}$ years. This is $5 \%$ of the total cumulative emissions over 40 years. In this example, although the emission estimate over the first 20 years is less than that over 40 years (i.e. not conservative), the 20 -year cut-off is operationally reasonable.

Excluding the changes in carbon stocks in dead wood and litter, as done in the EU Renewable Energy Directive, results in the underestimation of the emissions from deforestation by $33.7 \mathrm{tC} / \mathrm{ha}$. This is $12 \%$ of the total changes in carbon stocks in the first 20 years.

The annual changes in carbon stocks in the first 40 years are shown in Figure 10.

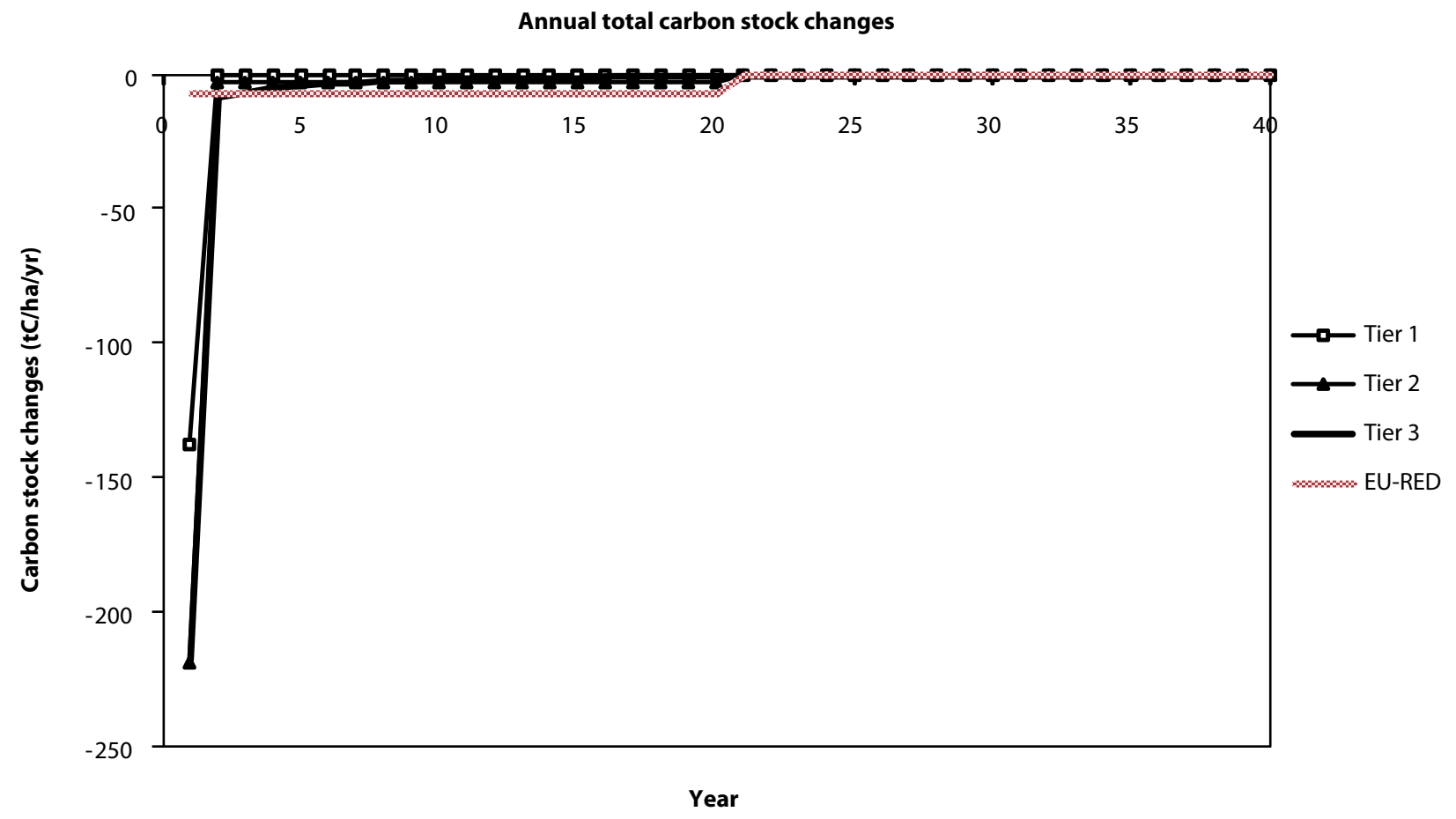

Figure 10. Deforestation example: Comparison of the total carbon stock changes by year under the 4 accounting methods 


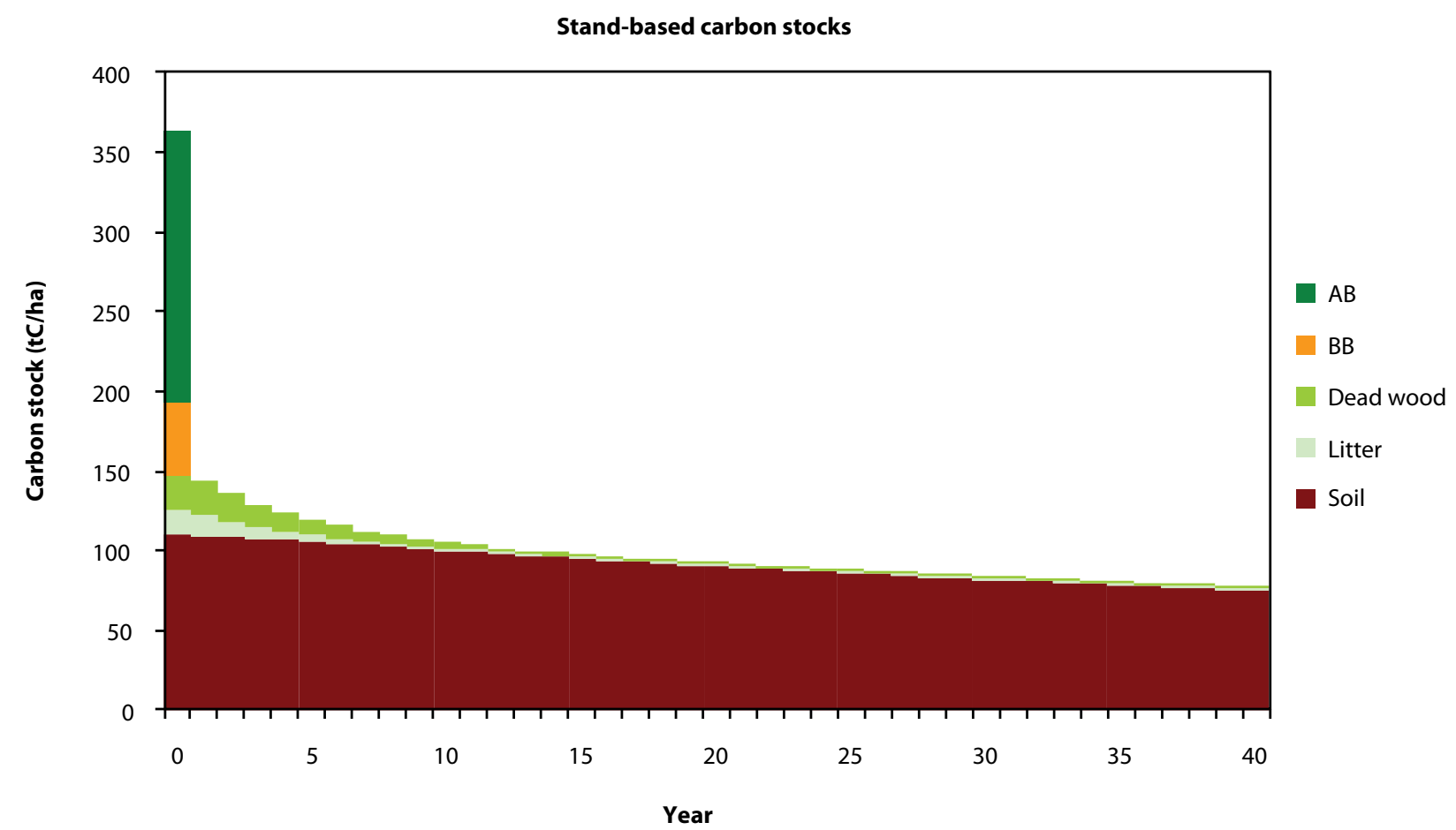

Figure 11. Deforestation example: Stand biomass 


\section{Conclusion}

I $\mathrm{n}$ this paper, we identified 4 methodologies for estimating the carbon stock changes from land use change. Three of the methodologies are taken from the 2006 IPCC Guidelines, which adopts a tiered approach: the lowest tier (Tier 1) uses default parameters for the estimation and a simplified methodology; the middle tier (Tier 2) uses in general the same methodology but with national or regional data to make the estimate; and the highest tier (Tier 3) makes use of complicated carbon flow models that are parameterised with regionally specific information. In addition, there are slight variations on this general approach depending on the type of land use change. The 4th methodology is taken from the EU Renewable Energy Directive, which adopts its own methodology but based on the approaches in the 2006 IPCC Guidelines (specifically Tier 1).

We examined the variations between the 4 methodologies using examples from the 4 types of land use changes that are most likely to affect forests:

1. land converted to forest - afforestation/ reforestation;

2. forest remaining forest - forest degradation;

3. forest remaining forest - use of harvest residuals, and

4. land converted to cropland - deforestation.

These examples have highlighted the necessity of:

- using Tier 2 or Tier 3 methods for calculating the carbon stock changes from land use changes that involve forestry;
- including dead wood and litter pools in the estimation of emissions, particularly when the land use change involves these pools directly or REDD+; and

- using a linearisation period over the first rotation and not fixing a specific predetermined length of time, if using a linear approximation to the forest carbon stock dynamics.

The first of these points has already been identified by numerous authors (Gibbs et al. 2007, Pelletier et al. in press). The need to use Tier 2 or 3 methods is due to the considerable uncertainty surrounding the default values used in the Tier 1 methodology. The same conclusion can be drawn for the EU Renewable Energy Directive, as its default tables are based on Tier 1 methodology. The regional variability in forest carbon stocks is well documented and is known to depend on temperature, elevation, precipitation, tree species composition, disturbance and soil fertility (Laurance et al. 1999, Clark and Clark 2000, Malhi et al. 2006, Urquiza-Haas et al. 2007). As is evident from the list of default values from the 2006 IPCC Guidelines (Table 6), the range of uncertainty is very large, especially for tropical forests $( \pm 100 \%)$. It is therefore unsurprising that the Tier 1 methodology provides so poor an estimate.

Table 7 lists the cumulative carbon stocks in over the first rotation as a percentage of the Tier 3 estimate. 
Table 6. Default values for aboveground biomass

\begin{tabular}{|c|c|c|c|c|}
\hline Domain & Ecological zone & Continent & $\begin{array}{l}\text { Aboveground biomass } \\
\left.\text { (tonnes d.m. ha' }{ }^{\cdot 1}\right)\end{array}$ & References \\
\hline \multirow[t]{20}{*}{ Tropical } & \multirow{4}{*}{$\begin{array}{l}\text { Tropical rain } \\
\text { forest }\end{array}$} & Africa & $310(130-510)$ & IPCC, 2003 \\
\hline & & North and South America & $300(120-400)$ & $\begin{array}{l}\text { Baker et al. 2004a; } \\
\text { Hughes et al. } 1999\end{array}$ \\
\hline & & Asia (continental) & $280(120-680)$ & IPCC 2003 \\
\hline & & Asia (insular) & $350(280-520)$ & IPCC 2003 \\
\hline & \multirow{4}{*}{$\begin{array}{l}\text { Tropical moist } \\
\text { deciduous forest }\end{array}$} & Africa & $260(160-430)$ & IPCC, 2003 \\
\hline & & North and South America & $220(210-280)$ & IPCC 2003 \\
\hline & & Asia (continental) & $180(10-560)$ & IPCC 2003 \\
\hline & & Asia (insular) & 290 & IPCC 2003 \\
\hline & \multirow{4}{*}{$\begin{array}{l}\text { Tropical dry } \\
\text { forest }\end{array}$} & Africa & $120(120-130)$ & IPCC 2003 \\
\hline & & North and South America & $210(200-410)$ & IPCC 2003 \\
\hline & & Asia (continental) & $130(100-160)$ & IPCC 2003 \\
\hline & & Asia (insular) & 160 & IPCC 2003 \\
\hline & \multirow{4}{*}{$\begin{array}{l}\text { Tropical } \\
\text { shrubland }\end{array}$} & Africa & $70(20-200)$ & IPCC 2003 \\
\hline & & North and South America & $80(40-90)$ & IPCC 2003 \\
\hline & & Asia (continental) & 60 & IPCC 2003 \\
\hline & & Asia (insular) & 70 & IPCC 2003 \\
\hline & \multirow{4}{*}{$\begin{array}{l}\text { Tropical } \\
\text { mountain } \\
\text { systems }\end{array}$} & Africa & $40-190$ & IPCC 2003 \\
\hline & & North and South America & $60-230$ & IPCC 2003 \\
\hline & & Asia (continental) & $50-220$ & IPCC 2003 \\
\hline & & Asia (insular) & $50-360$ & IPCC 2003 \\
\hline \multirow[t]{15}{*}{ Subtropical } & \multirow{3}{*}{$\begin{array}{l}\text { Subtropical } \\
\text { humid forest }\end{array}$} & North and South America & $220(210-280)$ & IPCC 2003 \\
\hline & & Asia (continental) & $180(10-560)$ & IPCC 2003 \\
\hline & & Asia (insular) & 290 & IPCC 2003 \\
\hline & \multirow{4}{*}{$\begin{array}{l}\text { Subtropical dry } \\
\text { forest }\end{array}$} & Africa & 140 & Sebei et al. 2001 \\
\hline & & North and South America & $210(200-410)$ & IPCC 2003 \\
\hline & & Asia (continental) & $130(100-160)$ & IPCC 2003 \\
\hline & & Asia (insular) & 160 & IPCC 2003 \\
\hline & \multirow{4}{*}{$\begin{array}{l}\text { Subtropical } \\
\text { steppe }\end{array}$} & Africa & $70(20-200)$ & IPCC 2003 \\
\hline & & North and South America & $80(40-90)$ & IPCC 2003 \\
\hline & & Asia (continental) & 60 & IPCC 2003 \\
\hline & & Asia (insular) & 70 & IPCC 2003 \\
\hline & \multirow{4}{*}{$\begin{array}{l}\text { Subtropical } \\
\text { mountain } \\
\text { systems }\end{array}$} & Africa & 50 & Montes et al. 2002 \\
\hline & & North and South America & $60-230$ & IPCC 2003 \\
\hline & & Asia (continental) & $50-220$ & IPCC 2003 \\
\hline & & Asia (insular) & $50-360$ & IPCC 2003 \\
\hline
\end{tabular}




\begin{tabular}{|c|c|c|c|c|}
\hline Domain & Ecological zone & Continent & $\begin{array}{l}\text { Aboveground biomass } \\
\text { (tonnes d.m. ha' }{ }^{-1} \text { ) }\end{array}$ & References \\
\hline \multirow[t]{12}{*}{ Temperate } & \multirow{4}{*}{$\begin{array}{l}\text { Temperate } \\
\text { oceanic forest }\end{array}$} & Europe & 120 & - \\
\hline & & North America & $660(80-1200)$ & $\begin{array}{l}\text { Hessl et al. 2004; } \\
\text { Smithwick et al. } 2002\end{array}$ \\
\hline & & New Zealand & $360(210-430)$ & Hall et al. 2001 \\
\hline & & South America & $180(90-310)$ & $\begin{array}{l}\text { Gayoso and Schlegel 2003; } \\
\text { Battles et al. } 2002\end{array}$ \\
\hline & \multirow{4}{*}{$\begin{array}{l}\text { Temperate } \\
\text { continental } \\
\text { forest }\end{array}$} & Asia, Europe ( $\leq 20$ y) & 20 & IPCC 2003 \\
\hline & & Asia, Europe (>20 y) & $120(20-320)$ & IPCC 2003 \\
\hline & & North and South America ( $\leq 20 \mathrm{y})$ & $60(10-130)$ & IPCC 2003 \\
\hline & & North and South America (>20 y) & $130(50-200)$ & IPCC 2003 \\
\hline & \multirow{4}{*}{$\begin{array}{l}\text { Temperate } \\
\text { mountain } \\
\text { systems }\end{array}$} & Asia, Europe ( $\leq 20$ y) & $100(20-180)$ & IPCC 2003 \\
\hline & & Asia, Europe (>20 y) & $130(20-600)$ & IPCC 2003 \\
\hline & & North and South America ( $\leq 20 \mathrm{y}$ ) & $50(20-110)$ & IPCC 2003 \\
\hline & & North and South America (>20 y) & $130(40-280)$ & IPCC 2003 \\
\hline \multirow[t]{5}{*}{ Boreal } & $\begin{array}{l}\text { Boreal coniferous } \\
\text { forest }\end{array}$ & Asia, Europe, North America & $10-90$ & Gower et al. 2001 \\
\hline & \multirow{2}{*}{$\begin{array}{l}\text { Boreal tundra } \\
\text { woodland }\end{array}$} & Asia, Europe, North America ( $\leq 20$ y) & $3-4$ & IPCC 2003 \\
\hline & & Asia, Europe, North America (>20 y) & $15-20$ & IPCC 2003 \\
\hline & \multirow{2}{*}{$\begin{array}{l}\text { Boreal mountain } \\
\text { systems }\end{array}$} & Asia, Europe, North America ( $\leq 20$ y) & $12-15$ & IPCC 2003 \\
\hline & & Asia, Europe, North America (>20 y) & $40-50$ & IPCC 2003 \\
\hline
\end{tabular}

Source: IPCC Guidelines 2006, Vol. 4

Table 7. Cumulative carbon stock changes over the first rotation as a percentage of the Tier 3 estimate

\begin{tabular}{lcccc}
\hline \multicolumn{1}{c}{ Activity } & IPCC & & EU Renewable Energy Directive \\
\hline Reforestation & Tier 1 & Tier 2 & Tier 3 & $-81 \%$ \\
Degradation & $10 \%$ & $-17 \%$ & $0 \%$ & $70 \%$ \\
Dead organic matter management & $-100 \%$ & $-2 \%$ & $0 \%$ & $-100 \%$ \\
Deforestation & $-44 \%$ & $0 \%$ & $0 \%$ & $-46 \%$ \\
\hline
\end{tabular}

Table 8. Cumulative carbon stock changes in DOM and SOC in the first 20 years as a percentage of the Tier 3 estimate

\begin{tabular}{lrrrc}
\hline \multicolumn{1}{c}{ Activity } & IPCC & & EU Renewable Energy Directive \\
\hline Reforestation & Tier 1 & Tier 2 & Tier 3 & $-93 \%$ \\
Degradation & $-78 \%$ & $-104 \%$ & $0 \%$ & $-100 \%$ \\
Dead organic matter management & $-100 \%$ & $43 \%$ & $0 \%$ & $-100 \%$ \\
Deforestation & $-52 \%$ & $0 \%$ & $0 \%$ & $-71 \%$ \\
\hline
\end{tabular}


Few authors have examined the impacts of including or excluding dead wood and litter. Table 8 displays the cumulative carbon stock changes in DOM and SOC in the first rotation as a percentage of the Tier 3 DOM and SOC estimates. This table shows that the Tiers 1 and 2 methodologies for carbon stock changes in DOM and SOC are very poor compared with the Tier 3 estimate.

Figure 12. shows the cumulative carbon stock changes in DOM and SOC in the first rotation as a percentage of the total carbon stock changes. The figure illustrates that these pools are significant (i.e. $>10 \%)$ in all 4 land use change cases. As the carbon stock changes in DOM and SOC are roughly proportional to the changes in aboveground biomass, the percentage contribution to the total cumulative biomass from these pools will be roughly independent of changes in aboveground biomass. The forest degradation case has a negative percentage because, as discussed above, the Tier 3 estimate suggests that there would be a loss of

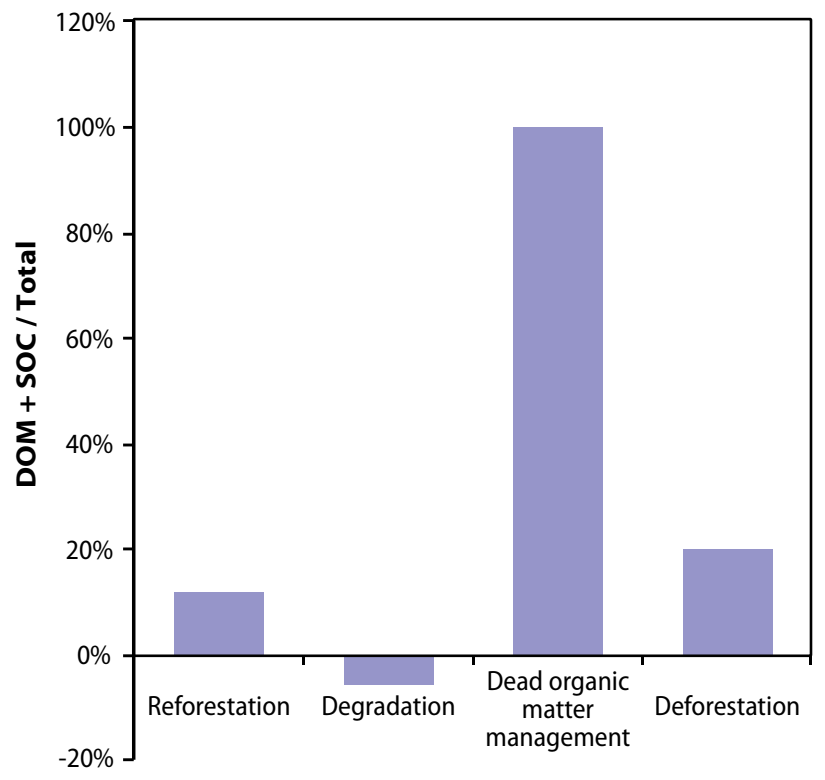

Figure 12. Cumulative carbon stock changes in dead organic matter (DOM) and soil organic carbon (SOC) in the first rotation as a percentage of the total carbon stock changes
SOC during the rotation whereas the Tiers 1 and 2 estimates only have an increase in SOC.

Finally, to our knowledge, no one has challenged the 20-year linearisation assumption adopted in the EU Renewable Energy Directive. As demonstrated by the examples and suggest previously in this section, a more realistic method for linearisation would be to amortise the carbon stock changes over the first rotation rather than adopt a fixed time of 20 years. Figure 13 shows the percentage of carbon stock changes in the first rotation that occur in the first 20 years. It indicates that the 20 -year fixed period is relatively good for the reforestation example but poor for the other examples. Clearly, the 20year period leads to poor estimates for systems with harvest rotations greater than 20 years. Furthermore, because the decay rate of DOM and SOC is roughly proportional to temperature and rainfall (Moore et al. 1999, Liski et al. 2003), the 20year fixed period method is increasingly poorer in colder climates.

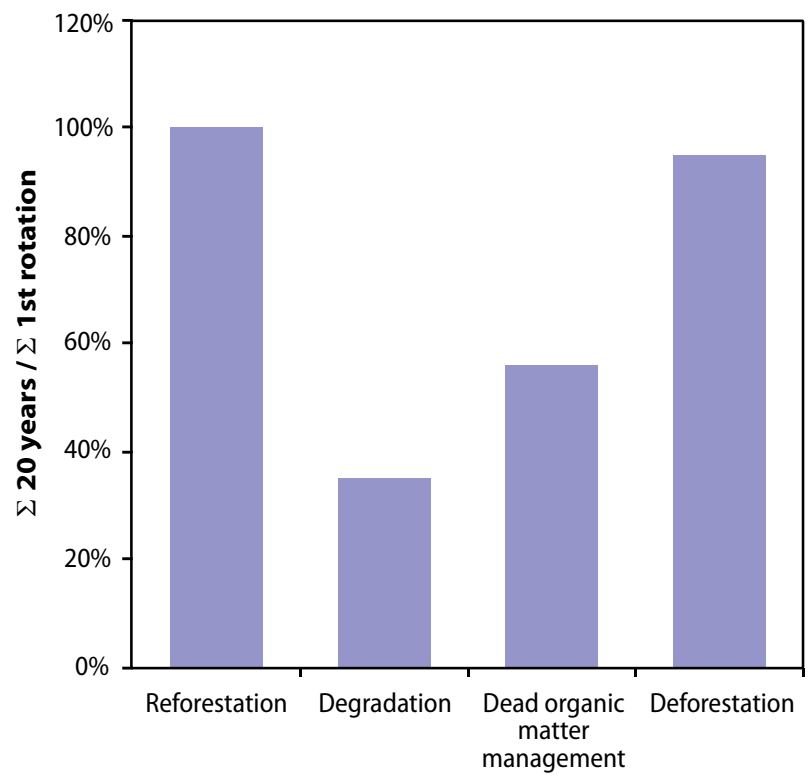

Figure 13. Cumulative carbon stock changes in the first 20 years as a percentage of the total carbon stock changes during the first rotation

Note: The deforestation case study does not have a rotation period. Instead, we have assumed a 40 -year period as representative of a rotation. 


\subsection{Ideas for improving carbon accounting methods}

As we explore improved methods for carbon accounting in another paper, we do not go into detail here. However, we do offer the following possibilities:

1. developing alternatives for allocating emissions from combustion of biomass for energy;

2. improving accounting of the timing of carbon changes;

3. including accounting of harvested wood products; and

4. including changes in surface albedo in the estimated greenhouse gas impacts of land use change.

\subsubsection{Developing alternatives for allocating emissions from combustion of biomass for energy}

As mentioned in Section 2.1.1, emissions from the combustion of biomass are counted as zero in the energy sector because they appear in the AFOLU sector. This has led to an overestimation of the benefits of bioenergy within the Kyoto Protocol because:

- some countries are not participating in the Kyoto Protocol (specifically developing countries); and

- in countries that are participating, some parts of the AFOLU sector are not included because only reporting carbon stock changes from afforestation, deforestation and reforestation is mandatory under the Kyoto Protocol. Hence reductions in carbon stock in a forest that remain forests may not be included.

Our preliminary thoughts on alternatives for allocating the emissions from combustion of biomass for energy were presented at the $18^{\text {th }}$ European Biomass Conference (Bird et al. 2010).

\subsubsection{Improving accounting for the timing of carbon stock changes}

Two issues have arisen over the timing of carbon stock changes when forest-based biomass is used for bioenergy:

1. forest-based bioenergy may cause a short-term decrease in carbon stocks; and

2. future carbon stock changes may have a different climate change impact to current carbon stock changes.

The short-term decrease in carbon stocks and its implications have been identified in 2 recent papers (Walker 2010, Zanchi et al. 2010). Both these papers identify that, in the short term (i.e. 10-30 years), using woody biomass for energy causes more emissions to enter the atmosphere than when using fossil fuels because wood combustion is less efficient than fossil fuel combustion. After this period, regrowth of the forest means that the woody biomass for energy is better than using fossil fuels.

In general, current accounting treats all carbon stock losses and gains over time as equal, but timing may be important. For example, an emission now may cause more damage than an emission in the future, and a removal now may have more benefits than a removal in the future. Although a few authors (Bird et al. 2008, 2009, O'Hare et al. 2009) have suggested this, there has been no agreement on how to properly discount or inflate for time (Kirschbaum 2003a, 2003b, Bird 2009).

\subsubsection{Including accounting of harvested wood products}

As mentioned in Section 2.1.2, harvested wood products (HWP), although included in the 2006 IPCC Guidelines framework, are not currently accounted for at all. However, in many tropical countries, forest removals are exceeding forest growth (i.e. non-renewable wood product extraction). Including the reduction in nonrenewable extraction outside the project boundary (i.e. positive leakage) would significantly improve the carbon stock gains of $\mathrm{A} / \mathrm{R}$ projects. 


\subsubsection{Including changes in surface albedo}

It has been noted that land use change can also change the surface albedo of the Earth. The change in albedo can cause more warming than the cooling caused by increased sequestration in the case of reforestation with coniferous species in areas with snow (Betts 2000). The deforestation of tropical forests also causes a change in surface albedo - in this case, cooling caused by changes in albedo and evapotranspiration overwhelm the warming caused by increased $\mathrm{CO}_{2}$ concentrations (Bala et al. 2007). We recently developed a model that combines albedo and carbon stock changes into a combined equivalent greenhouse gas emission or radiative forcing (Schwaiger and Bird 2009). The effects of including surface albedo change will be investigated using this model. 


\section{Endnotes}

1 http://www.efi.int/projects/casfor/

2 http://www.joanneum.at/gorcam.htm. The analysis used a modified GORCAM model that includes sub-modules for the calculation of litter, dead wood and soil decay rates. See ENCOFOR C_Model http://www.joanneum.at/ encofor/tools/tool_demonstration/download_ tools.htm.

3 Aboveground biomass includes all biomass of living vegetation, both woody and herbaceous, above the soil including stems, stumps, branches, bark, seeds and foliage.

4 Belowground biomass includes all biomass of live roots. Fine roots of less than (suggested) $2 \mathrm{~mm}$ in diameter are often excluded because these often cannot be distinguished empirically from soil organic matter or litter.

5 Dead wood includes all non-living woody biomass not contained in the litter, whether standing, lying on the ground or in the soil. Dead wood includes wood lying on the surface, stumps and dead roots, larger than or equal to $10 \mathrm{~cm}$ in diameter (or the diameter specified by the country).

6 Litter includes all non-living biomass with a diameter larger than the limit for soil organic matter (suggested $2 \mathrm{~mm}$ ) and less than the minimum diameter chosen for dead wood (e.g. $10 \mathrm{~cm}$ ), lying dead, in various states of decomposition above or within the mineral or organic soil. This includes the litter layer as usually defined in soil typologies. Live fine roots above the mineral or organic soil (of less than the minimum diameter limit chosen for belowground biomass) are included in litter where they cannot be distinguished from it empirically.

7 Soil includes organic carbon in mineral soils to a specified depth chosen by the country and applied consistently through the time series. Live and dead fine roots and dead organic matter (DOM) within the soil that are less than the minimum diameter limit (suggested $2 \mathrm{~mm}$ ) for roots and DOM are included with soil organic matter where they cannot be distinguished from it empirically. The default for soil depth is $30 \mathrm{~cm}$.

8 Harvested wood products (HWP) include all wood material (including bark) that leaves harvest sites. This includes wood fuel, paper, panels, boards, sawnwood, processing waste such as mill residues, sawdust and black liquor. The pool also includes discarded HWP that enter solid waste disposal (SWD) sites. Slash and other material left at harvest sites should be regarded as dead organic matter. HWP is included here for completeness but as the methodology for its accounting has not been agreed in international negotiations, it is not discussed further in this document.

9 An interesting but minor point is that the chosen values of carbon fraction do not coincide with the factor in the 2006 IPCC Guidelines in Table 4.3 or on page 2.23. 
10 These tables are equivalent to the values listed in the 2006 IPCC Guidelines. It seems redundant to display $R$ factors in Tables 16 and 18 because the values of $C_{V E G}$ are given (not $B_{A G B}$ ), but these $\mathrm{R}$ values are needed to convert Tier 1 values of $B_{A G B}$ given in the 2006 IPCC Guidelines to $C_{V E G}$. Values for open canopy forests are calculated assuming that they have $20 \%$ of the biomass of the equivalent closed cover forest and a given root-shoot ratio.
11 The estimated value in native forests comes from a Malaysian Palm Oil Board (MPOB) report that was not peer reviewed. Given the source, we expect that the value is low because it is in the interests of the MPOB that emissions from clearing for plantation establishment be as small as possible.

12 We use an Austrian example because it illustrates problems with the 20 -year transition accounting methodology proposed by the EU Renewable Energy Directive. 


\section{References}

Apps, M., Karajalainen, T., Marland, G. and Schlamadinger, B. 1997 Accounting system considerations: $\mathrm{CO}_{2}$ emissions from forests, forest products, and land-use change: a statement from Edmonton. http://www. ieabioenergy-task38.org/publications/ Accounting\%20System\%20Considerations.pdf (10 October 2010).

Bala, G., Caldeira, K., Wickett, M., Phillips, T.J., Lobell, D.B., Delire, C. and Mirin, A. 2007 Combined climate and carbon-cycle effects of large-scale deforestation. PNAS 104: 6550-6555.

Betts, R.A. 2000 Offset of the potential carbon sink from boreal forestation by decreases in surface albedo. Nature 408: 187-190.

Bird, D.N. 2009 On the timing of greenhouse gas emissions. Discussion paper prepared as part of the European Community Contribution Agreement EuropeAid/ENV/2007/143936/ TPS Bioenergy, sustainability and trade-offs: Can we avoid deforestation while promoting bioenergy? Joanneum Research, Graz, Austria.

Bird, D.N., Cherubini, F., Cowie, A., Downing, M., Gustavsson, L., Kojakovic, A., Jungmeier, G., Möllersten, K., Pingoud, K., Rueter S., et al. 2009 IEA bioenergy task 38 - ten years of analysing the greenhouse gas balances of bioenergy systems. Paper to 17th European Biomass Conference and Exhibition. Hamburg, Germany, 29 June -3 July.

Bird, D.N., Cowie, A., Frieden, D., Gustavsson, L., Pena, N., Pingoud, K., Rueter, S., Sathre, R., Soimakallio, S., Tuerk, A., et al. 2010 Emissions from bioenergy: improved accounting options and new policy needs. In: Proceedings of the 18th European Biomass Conference and Exhibition, Lyon, France.

Bird, D.N., Jungmeier, G., Marland, G. and Schwaiger, H. 2008 Integration of land use change into life-cycle analysis. Presented at IEA Bioenergy Task 38 Workshop - Transportation biofuels: for greenhouse gas mitigation, energy security or other reasons? Salzburg. http://www. ieabioenergy-task38.org (10 October 2010).

CDM Executive Board. 2007 Combined tool to identify the baseline scenario and demonstrate additionality in A/R CDM project activities (Version 01) http://cdm.unfccc.int/ methodologies/ARmethodologies/tools/ar-amtool-02-v1.pdf.

Clark, D.B. and Clark, D.A. 2000 Landscape-scale variation in forest structure and biomass in a tropical rain forest. Forest Ecology and Management 137:185-198.

European Union 2009 Directive 2009/28/EC of the European Parliament and of the Council of 23 April 2009 on the promotion of the use of energy from renewable sources and amending and subsequently repealing Directives 2001/77/EC and 2003/30/EC. http://eur-lex. europa.eu/LexUriServ/LexUriServ.do?uri= OJ:L:2009:140:0016:0062:EN:PDF.

European Union 2010a Communication from the Commission on the practical implementation of the EU biofuels and bioliquids sustainability scheme and on counting rules for biofuels. Official Journal of the European Union. 2010/C 160/02. http://eur-lex.europa.eu/LexUriServ/ LexUriServ.do?uri=OJ:C:2010:160:0008:0016:E $\mathrm{N}: \mathrm{PDF}$. 
European Union 2010b. Communication from the Commission on voluntary schemes and default values in the EU biofuels and bioliquids sustainability scheme. Official Journal of the European Union. 2010/C 160/01. http://eurlex.europa.eu/LexUriServ/LexUriServ.do?uri= OJ:C:2010:160:0001:0007:EN:PDF (10 October 2010).

European Union 2010c. Commission decision of 10 June 2010 on guidelines for the calculation of land carbon stocks for the purpose of Annex $\mathrm{V}$ to Directive 2009/28/EC. Official Journal of the European Union. 2010/335/EU. http://eur-lex. europa.eu/LexUriServ/LexUriServ.do?uri= OJ:L:2010:151:0019:0041:EN:PDF (10 October 2010).

Fargione, J., Hill, J., Tilman, D., Polasky, S. and Hawthorne, P. 2008 Land clearing and the biofuel carbon debt. Science 319: 1235.

Germer, J. and Sauerborn, J. 2008 Estimation of the impact of oil palm plantation establishment on greenhouse gas balance. Environment, Development and Sustainability 10: 697-716.

Gibbs, H.K., Brown, S., Niles, J.O. and Foley, J.A. 2007. Monitoring and measuring tropical forest carbon stocks: making REDD a reality. Environmental Research Letters 2(4): 045023. doi:10.1088/1748-9326/2/4/045023

Henson, I.E. 2004 Modelling carbon sequestration and greenhouse gas emissions associated with oil palm cultivation and land-use change In Malaysia. MPOB Technology 27.

Henson, I.E. 2008 The carbon cost of palm oil production in Malaysia. The Planter 84: 445-464.

Henson, I.E. 2009 Modelling carbon sequestration and greenhouse gas emissions associated with oil palm cultivation and land-use change in Malaysia: a re-evaluation and a computer model. MPOB Technology 31.

IPCC 1996 Revised 1996 IPCC guidelines for national greenhouse gas inventories. Houghton, J.T., Meira Filho, L.G., Lim, B., Tréanton, K., Mamaty, I., Bonduki, Y., Griggs, D.J. and Callander, B.A. (eds). IPCC WGI Technical Support Unit, Bracknell, UK.

IPCC 2000 Land use, land-change and forestry. A special report of the Intergovernmental Panel on Climate Change. (Watson, R., Noble, I., Bolin, B., Ravindranation, N., Verardo, D. and Dokken, D. (eds.) Cambridge University Press, Cambridge, UK.
IPCC 2003 Good practice guidance for land use, land-use change and forestry. Penman, J., Gytarsky, M., Hiraishi, T., Krug, T., Kruger, D., Pipatti, R., Buendia, L., Miwa, K., Ngara, T., Tanabe K. and Wagner, F. (eds.). The Institute for Global Environmental Strategies for the IPCC and IPCC National Greenhouse Gas Inventories Programme. Hayama, Kanagawa, Japan. http://www.ipcc-nggip.iges.or.jp/public/ gpglulucf/gpglulucf.html (10 October 2010).

IPCC 20062006 IPCC guidelines for national greenhouse gas inventories, volume 4: agriculture, forestry, and other land use. Eggleston H.S., Buendia L., Miwa K., Ngara T. and Tanabe K. (eds). IGES, Japan. http://www. ipcc-nggip.iges.or.jp/public/2006gl/index.html (10 October 2010).

Kirschbaum, M.U.F. 2003a. To sink or burn? A discussion of the potential contributions of forests to greenhouse gas balances through storing carbon or providing biofuels. Biomass and Bioenergy 24: 297-310.

Kirschbaum, M.U.F. 2003b Can trees buy time? An assessment of the role of vegetation sinks as part of the global carbon cycle. Climatic Change 58: 47-71.

Laurance W.F., Fearnside, P.M., Laurance, S.G., Delamonica, P., Lovejoy, T.E., Rankin-de Merona, J., Chambers, J.Q. and Gascon, C. 1999 Relationship between soils and Amazon forest biomass: a landscape-scale study. Forest Ecology and Management 118, 127-138.

Liski, J., Nissinen, A., Erhard, M. and Taskinen, O. 2003 Climatic effects on litter decomposition from arctic tundra to tropical rainforest. Global Change Biology 9(4): 575-584.

Malhi, Y., Wood, D., Baker, T.R., Wright, J., Phillips, O.L., Cochrane, T., Meir, P., Chave, J., Almeida, S., Arroyo, L., et al. 2006 The regional variation of aboveground live biomass in old-growth Amazonian forests. Global Change Biology 12: 1107-1138.

Marland, G. and Schlamadinger, B. 1995 Biomass fuels and forest management strategies: how do we calculate the greenhouse-gas emissions benefits? Energy 20: 1131-1140.

Mendoza-Vega, J., Karltun, E. and Olsson, M. 2003 Estimations of amounts of soil organic carbon and fine root carbon in land use and land cover classes, and soil types of Chiapas highlands, Mexico. Forest Ecology and Management 177: 191-206. 
Moore, T.R., Trofymow, J.A., Taylor, B., Prescott, C., Camire, C., Duschene, L., Fyles, J., Kozak, L., Kranabetter, M., Morrison, I., et al. 1999. Litter decomposition rates in Canadian forests. Global Change Biology 5(1): 75-82.

O'Hare, M., Plevin, R.J., Martin, J.I., Jones, A.D., Kendall, A. and Hopson, E. 2009 Proper accounting for time increases crop-based biofuels' greenhouse gas deficit versus petroleum. Environmental Research Letters 4: 024001. doi: 10.1088/1748-9326/4/2/024001.

Omar, R. Masera, J.F., Garza-Caligaris, Kanninen, M., Karjalainen, T., Liski, J., Nabuurs, G.J., Pussinen, A., de Jong, B.H.J. and Mohren, G.M.J. 2003 Modeling carbon sequestration in afforestation, agroforestry and forest management projects: the CO2FIX V.2 approach. Ecological Modelling 164: 177-199. http://www.efi.int/projects/casfor/downloads/ masera_et_al.pdf (10 October 2010).

Owen, D.L. (ed.) 2000 South African forestry handbook. Southern African Institute of Forestry, Pretoria, South Africa.

Pelletier, J., Kirby, K.R. and Potvin, C. In press Significance of carbon stock uncertainties on emission reductions from deforestation and forest degradation in developing countries. Forest Policy and Economics. doi:10.1016/j. forpol.2010.05.005.

Pingoud, K., Cowie, A., Bird, N., Gustavsson, L., Rüter, S., Sathre, R., Soimakallio, S., Türk, A. and Woess-Gallasch, S. 2010 Bioenergy: counting on incentives. Science 327: 1199.

Schlamadinger, B. and Marland, G. 1996. The role of forest and bioenergy strategies in the global carbon cycle. Biomass and Bioenergy 10: 275-300.

Scholes, R.J. 1997 NPP grassland: Nylsvley, South Africa, 1974-1989. Data set. Oak Ridge National Laboratory Distributed Active Archive Center, Oak Ridge, Tennessee, USA. http://www.daac.ornl.gov (10 October 2010).

Schwaiger, H.P. and Bird, D.N. 2009 Integration of albedo effects caused by land use change into the climate balance: should we still account in greenhouse gas units? Forest Ecology and Management. 260: 278-286.
Searchinger, T., Heimlich, R., Houghton, R.A., Dong, F., Elobeid, A., Fabiosa, J., Tokgoz, S., Hayes, D., Yu, T.-H. 2008 Use of US croplands for biofuels increases greenhouse gases through emissions from land-use change. Science 319: 1238.

Snyman, H.A. 2005 Short-term influence of fire in a semi-arid grassland: root distribution, seasonal root production and root/shoot ratio. Grassroots: Newsletter of the Grassland Society of Southern Africa. 5/3.

South African Weather Service. 2009 Average climate data for Pietermaritzburg for 19611990. http://www.weathersa.co.za/Climat/ Climstats/Pietermaritzburg.html.

Urquiza-Haas, T., Dolman, P.M. and Peres, C.A. 2007 Regional scale variation in forest structure and biomass in the Yucatan Peninsula, Mexico: effects of forest disturbance. Forest Ecology and Management 247: 80-90.

Walker, T. (ed.) 2010 Biomass sustainability and carbon policy study: report to the Commonwealth of Massachusetts Department of Energy Resources. Manomet Center for Conservation Sciences. Report No.: NCI2010-03.

Winckler Caldeira M., Valdir Schumacher, M. and Spathelf, P. 2002 Quantification of nutrient content in above-ground biomass of young Acacia mearnsii De Wild., provenance Bodalla. Annals of Forest Science 59: 833-838.

ZAMG. 2009 http://www.zamg.ac.at/klima/ klimadaten/index.php (10 October 2010).

Zanchi, G., Pena, N. and Bird, N. 2010. The upfront carbon debt of bioenergy. Report for Birdlife International by Joanneum Research. http://www.birdlife.org/eu/pdfs/Bioenergy_ Joanneum_Research.pdf (10 October 2010).

Zinke, P.J., Stangenberger, A.G., Post, W.M., Emanuel, W.R. and Olson, J.S. 1986 Worldwide organic soil carbon and nitrogen data, NDP018. Carbon Dioxide Information Analysis Center (CDIAC), Oak Ridge National Laboratory, Oak Ridge, Tennessee. http://cdiac. esd.ornl.gov/ ndps/ndp018.html (10 October 2010). 


\section{Annex - Parameters}

\section{Reforestation: Grassland to forest: South Africa - short rotation forestry}

\begin{tabular}{|c|c|c|c|}
\hline Item & Tier 1 & Tier 2 & Tier 3 \\
\hline \multicolumn{4}{|l|}{ Woody biomass } \\
\hline $\begin{array}{l}\text { Mean annual } \\
\text { increment at harvest }\end{array}$ & $\begin{array}{l}10 \text { t d.m./ } \\
\text { ha/a }\end{array}$ & 8.9 t d.m./ha/a & 8.9 t d.m./ha/a \\
\hline Description & Linear & Curvilinear & Curvilinear \\
\hline Source & Table $4.10^{\mathrm{a}}$ & Owen 2000 & Owen 2000 \\
\hline $\mathrm{BCEF}_{\mathrm{R}}$ & & 0.89 t d.m. $/ \mathrm{m}^{3}$ & 0.89 t d.m. $/ \mathrm{m}^{3}$ \\
\hline Source & & Table 4.5 & Table 4.5 \\
\hline $\mathrm{R}: \mathrm{S}$ & 0.28 & 0.28 & 0.28 \\
\hline Source & Table 4.4 & Table 4.4 & Table 4.4 \\
\hline Dead wood at 20 years & n.a. & 0 & \\
\hline Assumptions & & & $\begin{array}{l}\text { Modelled, assuming } 1.77 \% \text { of } A B \text { is annual dead } \\
\text { wood }\end{array}$ \\
\hline Source & Table 2.2 & $\begin{array}{l}\text { Winckler Caldeira } \\
2002\end{array}$ & IPCC 2003 (Table 3.2.2) \\
\hline Wood CF & 0.47 & 0.47 & 0.47 \\
\hline Source & Table 4.3 & Table 4.3 & Table 4.3 \\
\hline Litter at 20 years & $2.1 \mathrm{tC} / \mathrm{ha}$ & & $24.0 \mathrm{tC} / \mathrm{ha}$ \\
\hline Assumptions & & & $\begin{array}{l}\text { Modelled, assuming } 22.5 \% \text { of } A B \text { is foliage, foliage is } \\
\text { shed annually and all foliage goes to litter at harvest }\end{array}$ \\
\hline Source & Table 2.2 & & Winckler Caldeira 2002 \\
\hline Litter CF & 0.37 & 0.37 & 0.37 \\
\hline Source & Table 4.3 & Table 4.3 & Table 4.3 \\
\hline \multicolumn{4}{|l|}{ Non-woody biomass } \\
\hline Grassland $A B$ & & $1.53 \mathrm{t} / \mathrm{ha}$ & $1.53 \mathrm{t} / \mathrm{ha}$ \\
\hline Source & & Scholes 1997 & Scholes 1997 \\
\hline Grassland BB & & $3.40 \mathrm{t} / \mathrm{ha}$ & $3.40 \mathrm{t} / \mathrm{ha}$ \\
\hline Source & & Estimated & Estimated \\
\hline Grassland R:S & & 2.22 & 2.22 \\
\hline Source & & Snyman 2005 & Snyman 2005 \\
\hline Grassland litter & & $1.98 \mathrm{t} / \mathrm{ha}$ & $1.98 \mathrm{t} / \mathrm{ha}$ \\
\hline Source & & Scholes 1997 & Scholes 1997 \\
\hline Grass CF & & 0.47 (IPCC 2006) & 0.47 (IPCC 2006) \\
\hline \multicolumn{4}{|l|}{ Soil } \\
\hline Soil at 0 years & $30.1 \mathrm{tC} / \mathrm{ha}$ & $36.5 \mathrm{tC} / \mathrm{ha}$ & $36.5 \mathrm{tC} / \mathrm{ha}$ \\
\hline Source & $\begin{array}{l}\text { Table } 2.2 \\
\text { Table } 6.2\end{array}$ & $\begin{array}{l}\text { Table } 6.2 \text { and } \\
\text { Zinke et al. } 1986\end{array}$ & Table 6.2 and Zinke et al. 1986 \\
\hline $\begin{array}{l}\text { Soil at } 20 \text { years } \\
\text { Source }\end{array}$ & $\begin{array}{l}31.0 \mathrm{tC} / \mathrm{ha} \\
\text { Table } 2.2\end{array}$ & $\begin{array}{l}37.6 \mathrm{tC} / \mathrm{ha} \\
\text { Zinke et al. } 1986\end{array}$ & Modelled \\
\hline \multicolumn{4}{|l|}{ Climate } \\
\hline Average temperature & & & $18.5^{\circ} \mathrm{C}$ \\
\hline Annual precipitation & & & $844 \mathrm{~mm}$ \\
\hline Source & & & $\begin{array}{l}\text { Pietermaritzburg (South African Weather Service } \\
\text { 2009) }\end{array}$ \\
\hline
\end{tabular}

a Table numbers refer to tables in 2006 IPCC Guidelines, unless otherwise stated. 


\section{Forest degradation: Unmanaged forests to plantations: Malaysia - palm plantations on native forest}

\begin{tabular}{|c|c|c|c|}
\hline Item & Tier 1 & Tier 2 & Tier 3 \\
\hline \multicolumn{4}{|c|}{ Unmanaged forest } \\
\hline $\begin{array}{l}\text { Unmanaged } \\
\text { forest biomass }\end{array}$ & 350 t d.m./ha & 239 t d.m./ha & 239 t d.m./ha \\
\hline Source & Table $4.7^{\mathrm{a}}$ & Henson 2009 & Henson 2009 \\
\hline $\mathrm{R}: \mathrm{S}$ & 0.37 & 0.37 & 0.37 \\
\hline Source & Table 4.4 & Table 4.4 & Table 4.4 \\
\hline $\begin{array}{l}\text { Dead wood at } \\
0 \text { years }\end{array}$ & n.a. & 0.0 tC/ha & 7.0 tC/ha \\
\hline Assumptions & & & Modelled, assuming $1.77 \%$ of $A B$ is annual dead wood \\
\hline Source & & Table 2.2 & IPCC 2003 (Table 3.2.2) \\
\hline Litter at 0 years & n.a. & $2.1 \mathrm{tC} / \mathrm{ha}$ & $2.0 \mathrm{tC} / \mathrm{ha}$ \\
\hline Assumptions & & & $\begin{array}{l}\text { Modelled, assuming } 2 \% \text { of } A B \text { is foliage, foliage is shed } \\
\text { annually and all foliage is burnt at clearing }\end{array}$ \\
\hline Source & & Table 2.2 & Typical value for deciduous species \\
\hline Soil at 0 years & $44.0 \mathrm{tC} / \mathrm{ha}$ & $44.0 \mathrm{tC} / \mathrm{ha}$ & 44.0 tC/ha \\
\hline Source & Table 2.3 & Table 2.3 & Table 2.3 \\
\hline \multicolumn{4}{|l|}{ Palm plantation } \\
\hline $\begin{array}{l}\text { Mean annual } \\
\text { increment at } \\
\text { harvest }\end{array}$ & 5.0 t d.m./ha/a & 3.7 t d.m./ha/a & 3.7 t d.m./ha/a \\
\hline Description & Linear & Curvilinear & Curvilinear \\
\hline Source & Table 4.10 & $\begin{array}{l}\text { Germer and } \\
\text { Sauerborn } \\
2008\end{array}$ & Germer and Sauerborn 2008 \\
\hline $\mathrm{R}: \mathrm{S}$ & 0.37 & 0.37 & 0.37 \\
\hline Source & Table 4.4 & Table 4.4 & Table 4.4 \\
\hline $\begin{array}{l}\text { Dead wood at } \\
20 \text { years }\end{array}$ & n.a. & n.a. & $0.0 \mathrm{tC} / \mathrm{ha}$ \\
\hline Source & & & Modelled, assumes no dead wood production \\
\hline Litter at 20 years & n.a. & $3.6 \mathrm{tC} / \mathrm{ha}$ & $3.4 \mathrm{tC} / \mathrm{ha}$ \\
\hline Assumptions & & & $\begin{array}{l}\text { Modelled, assuming } 11 \% \text { of } A B \text { is foliage, foliage is shed } \\
\text { annually and all foliage is burnt at plantation renewal }\end{array}$ \\
\hline Source & & Henson 2008 & Henson 2008 \\
\hline Soil at 20 years & $44.0 \mathrm{tC} / \mathrm{ha}$ & $55.0 \mathrm{tC} / \mathrm{ha}$ & $46.7 \mathrm{tC} / \mathrm{ha}$ \\
\hline Source & Table 2.3 & Henson 2004 & Modelled \\
\hline \multicolumn{4}{|l|}{ Climate } \\
\hline $\begin{array}{l}\text { Average } \\
\text { temperature }\end{array}$ & & & $27.8^{\circ} \mathrm{C}$ \\
\hline $\begin{array}{l}\text { Annual } \\
\text { precipitation }\end{array}$ & & & $2403 \mathrm{~mm}$ \\
\hline Source & & & Kuala Lumpurb \\
\hline
\end{tabular}

a Table numbers refer to tables in 2006 IPCC Guidelines, unless otherwise stated.

b http://www.weather.com/outlook/events/weddings/wxclimatology/monthly/MYXX0008 


\section{Forest management: Use of harvest residuals: Austria - collection of thinning and harvest residuals}

\begin{tabular}{|c|c|c|}
\hline Item & Tier 1 & Tier 2 and Tier 3 \\
\hline $\begin{array}{l}\text { Mean annual increment } \\
\text { at harvest }\end{array}$ & & 4.7 \\
\hline Description & & Curvilinear \\
\hline Source & & Austrian National Biomass Tables \\
\hline $\mathrm{R}: \mathrm{S}$ & & 0.29 \\
\hline Source & & IPCC 2006 (Table 4.4) \\
\hline Dead wood at 20 years & & $\begin{array}{l}\text { Without residual removal } 24.6 \mathrm{t} \mathrm{C} / \mathrm{ha} \\
\text { With residual removal } 19.0 \mathrm{t} \mathrm{C/ha}\end{array}$ \\
\hline Assumptions & & $\begin{array}{l}\text { Modelled, assumes } 14 \% \text { of } A B \text { is branches } \\
1.77 \% \text { of } A B \text { is annual dead wood production }\end{array}$ \\
\hline Source & & $\begin{array}{l}\text { Average value for Picea abies from JRC Database of forest biomass } \\
\text { compartments (http://afoludata.jrc.it/); IPCC } 2003 \text { (Table 3.2.2) }\end{array}$ \\
\hline Litter at 20 years & & $\begin{array}{l}\text { Without residual removal } 3.2 \mathrm{t} \mathrm{C} / \mathrm{ha} \\
\text { With residual removal } 3.2 \mathrm{t} \mathrm{C/ha}\end{array}$ \\
\hline Assumptions & & Modelled, assumes $11 \%$ of biomass is branches \\
\hline Source & & $\begin{array}{l}\text { Average value for Picea abies from JRC Database of forest biomass } \\
\text { compartments (http://afoludata.jrc.it/) }\end{array}$ \\
\hline Soil at 20 years & & $\begin{array}{l}\text { Without residual removal } 72.2 \mathrm{t} \mathrm{C} / \mathrm{ha} \\
\text { With residual removal } 68.9 \mathrm{t} \mathrm{C/ha}\end{array}$ \\
\hline Source & & Modelled \\
\hline \multicolumn{3}{|l|}{ Climate } \\
\hline Average temperature & & $8.7^{\circ} \mathrm{C}$ \\
\hline Annual precipitation & & $778 \mathrm{~mm}$ \\
\hline Source & & Bruck an der Mur (ZAMG 2009) \\
\hline
\end{tabular}




\section{Deforestation: Forests to cropland: Mexico - a mixed pine/oak forest converted to cornfield}

\begin{tabular}{|c|c|c|}
\hline Item & Tier 1 & Tier 2 / 3 \\
\hline \multicolumn{3}{|l|}{ Unmanaged forest } \\
\hline $\begin{array}{l}\text { Unmanaged forest } \\
\text { biomass }\end{array}$ & 210 t d.m./ha & 359.4 t d.m./ha \\
\hline Source & Table $4.7^{\mathrm{a}}$ & Omar et al. 2003 \\
\hline$R: S$ & 0.28 & 0.28 \\
\hline Source & Table 4.4 & Table 4.4 \\
\hline Dead wood at 0 years & $8.6 \mathrm{tC} / \mathrm{ha}$ & $21.5 \mathrm{tC} / \mathrm{ha}$ \\
\hline Assumptions & & Modelled, assuming $1.77 \%$ of $A B$ is annual dead wood \\
\hline Source & IPCC 2003 (Table 3.2.2) & IPCC 2003 (Table 3.2.2) \\
\hline Litter at 0 years & $2.1 \mathrm{tC} / \mathrm{ha}$ & $13.9 \mathrm{tC} / \mathrm{ha}$ \\
\hline Assumptions & & $\begin{array}{l}\text { Modelled, assuming } 3.3 \% \text { of } A B \text { is foliage that is shed } \\
\text { annually and all foliage is burnt at clearing }\end{array}$ \\
\hline Source & Table 2.2 & $\begin{array}{l}\text { Typical value for coniferous species } \\
\text { Omar et al. } 2003\end{array}$ \\
\hline Soil at 0 years & $35.0 \mathrm{tC} / \mathrm{ha}$ & $111.1 \mathrm{tC} / \mathrm{ha}$ \\
\hline Source & Table 2.3 & Table 2.3. Model parameters chosen to create this value \\
\hline \multicolumn{3}{|l|}{ Cornfield } \\
\hline Average yield & & $16.2 \mathrm{t} / \mathrm{ha}$ \\
\hline Source & & Mendoza-Vega 2003 \\
\hline Average residues & & $26.4 \mathrm{t} / \mathrm{ha}$ \\
\hline Source & & Calculated, Table 11.2 \\
\hline $\mathrm{R}: \mathrm{S}$ & 0.37 & 0.20 \\
\hline Source & Table 4.4 & IPCC 2006 \\
\hline $\begin{array}{l}\text { Dead wood at } 20 \text { years } \\
\text { Source }\end{array}$ & 0 tC/ha & $\begin{array}{l}0.5 \mathrm{tC} / \mathrm{ha} \\
\text { Modelled }\end{array}$ \\
\hline $\begin{array}{l}\text { Litter at } 20 \text { years } \\
\text { Assumptions } \\
\text { Source }\end{array}$ & 0 tC/ha & $\begin{array}{l}1.1 \mathrm{tC} / \mathrm{ha} \\
\text { Modelled }\end{array}$ \\
\hline Soil at 20 years & $19.3 \mathrm{tC} / \mathrm{ha}$ & $90.2 \mathrm{tC} / \mathrm{ha}$ \\
\hline Source & Table 2.3 & Modelled \\
\hline \multicolumn{3}{|l|}{ Climate } \\
\hline Average temperature & & $16.0^{\circ} \mathrm{C}$ \\
\hline Annual precipitation & & $1567 \mathrm{~mm}$ \\
\hline Source & & Oxchuc, Chiapas (http://smn.cna.gob.mx/) \\
\hline
\end{tabular}

a Table numbers refer to tables in 2006 IPCC Guidelines (IPCC 2006), unless otherwise stated. 


Forests and forest land provide biomass that can be used to create forest-based bioenergy, whether through the establishment of energy plantations on non-forestland, use of existing forest resources or the use of residues that result from harvesting for non-bioenergy purposes. If produced in a sustainable manner, this bioenergy can have significant positive greenhouse gas benefits. However, past experience provides strong reason to believe that bioenergy development on a large scale will come at the expense of natural forests, either through direct conversion of forests to other land uses or through indirect competition between land uses. For example, bioenergy development may increase the demand for agricultural land, which may be converted from tropical forests. In this case, the net carbon balance would in most cases be highly negative.

This paper first reviews methods for carbon accounting for forest-based bioenergy development employed by the Intergovernmental Panel on Climate Change and the EU - Renewable Energy Directive. The paper then uses examples to illustrate the benefits and shortcomings of the reviewed methodologies. The examples were chosen to highlight specific cases of land use change that may occur as a result of bioenergy development. These examples highlight the necessity of:

- using Tier 2 or Tier 3 methods to calculate the carbon stock changes from land use changes affecting forests;

- including dead wood and litter pools in the estimation of emissions, particularly when estimating emissions from deforestation and when the land use change involves only these pools; and

- using a linear approximation over the first rotation and not a specific predetermined length of time, if a simplified forest carbon stock dynamics is to be used.

CIFOR Occasional Papers contain research results that are significant to tropical forestry. The content is peer reviewed internally and externally.

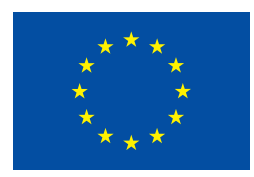

